\title{
The Qarakhanid Silk Roads and Beyond
}

Introduction

Historical trade roads across Eurasia are usually associated with the so-called Silk Road. Its image is very well-known among scholars, travelers, and politicians. At the same time, the concept of the Silk Roads is an entirely abstract invention of 19th-century scholarship and mainly refers to ancient international trade networks dominant in China and Central Asia that functioned in the east-west direction. The Silk Road has been widely investigated in recent years, even spawning a new discipline in humanities known as "Silk Road Studies." But it is clear that silk was not even the primary commodity traded across Eurasia, as international trade in the ancient world was much more complex and far-flung, and its routes and directions cannot always be easily fitted into the concept of the "Silk Road." It refers specifically to Qarakhanid international trade that not only developed existed networks but, in some cases, invented new passages to control the movement of the most high-value products along ancient routes such as amber, frankincense, and tea.

This chapter deals with the Qarakhanid trade roads and networks beyond the Silk Roads through analyzing Song dynasty texts on commodities transported by Qarakhanid caravans to China involving Central Asian sources and relevant archaeological data. I present the Silk Road images during the Liao and Song periods in China and introduce Qarakhanid activities in the amber, frankincense and tea trades.

This section utilizes archaeological materials on so-called huren (foreigner) figurines unearthed from the Liao and Song tombs and examines images portrayed by Song artists that may refer to Central Asia.

Archaeological materials are crucial to studying the history of cross-cultural contacts and exchanges between China and Central Asia. Some material findings or historical sites often become symbols of contacts along the Silk Road. For instance, Tang ceramic figures of huren and the tomb of An Jia representing Turks and Sogdians in China, or the Afrasiyab painting in Samarqand depicting Chinese, Korean, and Iranian ambassadors are well-known in academic 
and museum circles and widely presented in scholarship. Generally speaking, the majority of the famous Silk Road symbols are archaeological discoveries involving the Sogdians. In fact, the large number of cultural relics and archaeological findings unearthed in Liao tombs also contain data about contacts and exchanges between China, Central Asia and beyond. Many excavations of Liao and Song sites, except some tombs, are conducted and supported by local teams and are published mainly in Chinese journals. Therefore these artifacts remain obscure and relatively unrepresented outside of China.

Below, I will focus on Liao and Song materials that contain cultural relics related to contacts along the Silk Road. I will discuss images of foreigners or so-called huren that were unearthed in Liao and Song tombs. The concept of huren was used differently in the post-Tang period. For instance, the Khitans, the Tanguts and the Jurchens were also viewed as huren in Song China and it was not as widely associated with Central Asian merchants as it was during the Tang. ${ }^{1}$ But for simplicity, I will follow Chinese archaeologists and use this term discussing Central Asian images in Liao and Song China. Additionally, I will also briefly introduce some rare findings of Song coins that have been recently discovered in Kyrgyzstan and Russia.

\subsection{Hu Artists in Liao China}

The most famous archaeological findings related to the Liao contacts with the Qarakhanids and the Islamic world were found in the Liao Tomb of the Princess of Chen and her husband Xiao Shaoju, who were buried together in 1018 in the place known as Qinglongshan in Naiman Banner, Inner Mongolia and unearthed from 1983 to 1986 . They were discovered lying on a brick funerary bed and their bodies were covered with precious metals and metal netting, from golden crowns and masks on their heads and faces to the gold and silver boots on their feet. Many precious objects discovered from the tomb were originally produced outside of the Liao realm such as Khotan jade, Islamic glass vessels, Baltic amber, and a metal bowl bearing an inscription in Arabic. These foreign objects reached Liao China as a result of Qarakhanid trade along the Silk Road. ${ }^{2}$

Among numerous pieces of amber, jade, agate and coral jewelry, the archaeologists also discovered an amber figure of a foreigner bearing a lion (Figure 4). The man wears a conical hat and a scarf wrapped around his head,

1 Yang Rui 杨猜, “Lun Songdai de huren 论宋代的胡人 [Huren during the Song Dynasty],” Zhongguo bianjiang shidiyanjiu 中国边疆史地研究 1 (2011): 87-94.

2 These materials are published in the catalogue of the exhibition Gilded Splendor: Treasures of China's Liao Empire (907-1125), see Shen, Schätze der Liao. 


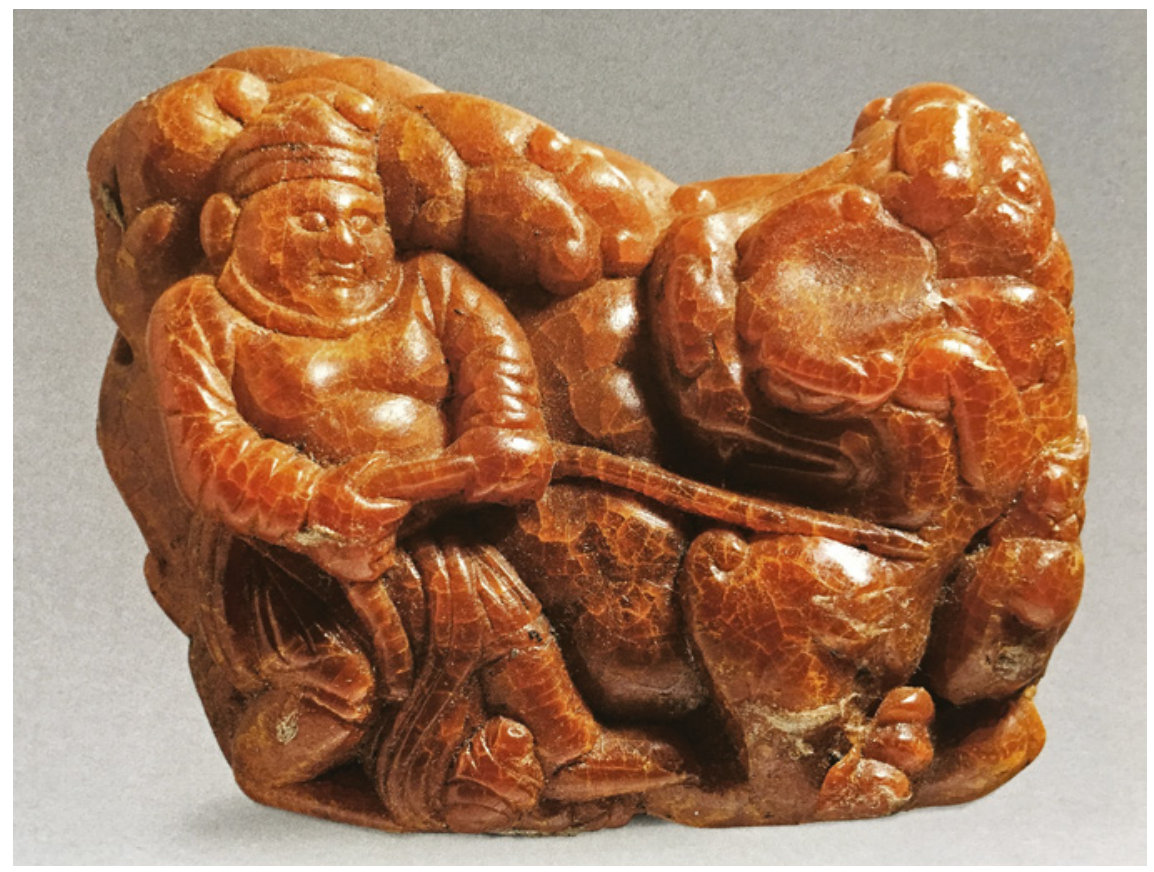

FIGURE 4 Foreign Envoy Presenting a Lion, Amber Plaque from the Liao Tomb of the Princess of Chen and her husband Xiao Shaoju, Qinglongshan town, Naiman Banner INNER MONGOLIA INSTITUTE OF CULTURAL RELICS AND ARCHAEOLOGY (AFTER SHEN ED. SCHÄTZE DER LIAO, FIG. 77, P. 285)

and resembles the famous Tang images of huren. This figure could be a representation of a Central Asian envoy offering a lion to the Liao emperor, apparently a Qarakhanid messenger.

It is known from Chinese official sources that the lion was presented in the list of commodities brought by the Qarakhanids to the Song court and obviously was also sent as a gift to the Liao emperor. ${ }^{3}$ Moreover, the Northern Song artist Li Gonglin painted the Yutian guo gong shizi tu (Portrait of Khotanese envoys presenting a lion). This portrait was mentioned by the Southern Song writer Zhou Mi (1232-1298) in his art catalog. ${ }^{4}$ It indicates that images of Qarakhanid envoys presenting lions were common both in Liao and Song China. I am not aware of the location of this portrait and whether it has survived until today.

3 Xu Zizhi tongjian changbian, 362: 8655, 8658; Song shi, 17: 320-321, 490: 14109; Song huiyao jigao, Fanyi 7: 38 .

4 Yunyan guaoyan lu, 23. For other works depicting lions from Khotan and the Western Regions, see Yunyan guaoyan lu, 12. 
This is not the only image of Central Asians found in the Liao sites. These materials are known in Chinese archaeology but rarely studied outside of China. Yang Rui has recently provided an overview of huren images found from tombs of the Five Dynasties, Liao, and Song periods. ${ }^{5}$ For example, a threecolor pottery bowl with a scene of a huren training a lion and playing a musical instrument was discovered in 1959 in the Liao tomb, which dates from the second half of the eleventh century in Xiaoliuzhangzi village, Ningcheng, Inner Mongolia (Figure 5). The bowl is octagonal and the lion-training scene appears on each side. The foreign artist, wearing a knee-length robe, a triangular scarf around his waist, a triangular hat, and soft boots, is depicted dancing with the lion and playing a musical instrument known as huqin. ${ }^{6}$

A Liao porcelain statue of a foreigner riding a lion was found in Lamagou village in Aohan Banner, Inner Mongolia in 1984 (Figure 6). The lion with the saddle stands on a rectangular base and the man sits on the lion playing a type of lute known as pipa. He wears a long light red robe and a petal-like curled hat, the two sides of which are tied with ropes under the collar, and carries on a pot on his back. ${ }^{7}$

Lions are not native to either China or the Khitans. They were a common gift from delegations from Central Asia and Iran starting from the Han period and were strongly associated with foreigners from these regions. The lion image became a popular motif in Chinese culture, as it was believed that lions could expel evil. The image of the lion in Liao China was also widely used in decoration, paintings and sculpture. Lion performances, which integrate singing, dancing, music, and acrobatics, share typical characteristics with the Western Regions in terms of content and form of expression. The famous Lion Dance,

5 Yang Rui 杨蓕, Huigu shidai:10-13 shiji lushang sichou zhi lu maoyi yanjiu 回鹘时代: 10-13 世纪陆上丝绸之路贸易研究 [The Uyghur Era: A Study on the Overland Silk Road in the 1oth-13th Centuries] (Beijing: Zhongguo shehui kexue chubanshe, 2015).

6 Li Yiyou 李逸友, “Zhaowudameng Ningchengxian Xiaoliuzhangzi Liao mu fajue jianbao 昭乌达盟宁城县小刘仗子 辽幕发掘简报 [Brief Report on the Excavation of the Liao Tomb from Xiaoliuzhangzi in Ningcheng County, Zhaowu Dameng],” Wenwu 文物9 (1961): 44-51; Lu Fuhua 吕富华, “Cong chutu de huren xunshihupo peishi kan xifan wenhua yinsu dui Liaowenhua de yingxiang 从出土的胡人驯狮琥珀佩饰看西方文化因素对辽文化 的影响 [The Influence of Western Cultural Factors on Liao Culture from Unearthed Amber Ornaments of Hu People Tame Lions]," Chifeng xueyuanxuebao (hanwen zhexue shehui kexue ban) 赤峰学院学报(汉文哲学社会科学版) 35, no. 2 (2014): 16.

7 Shao Guotian 邵国田, “Neimenggu Aohanqi faxian huren qi shi Liaoci xiang 内蒙古敖汉 旗发现胡人骑狮辽瓷像 [The Discovery of the Liao Porcelain Statue of the Hu Man Riding a Lion in Aohan Banner, Inner Mongolia]," Beifang wenwu 北方文物 2 (1988): 38; Lu, "Cong chutu de huren," 16. 


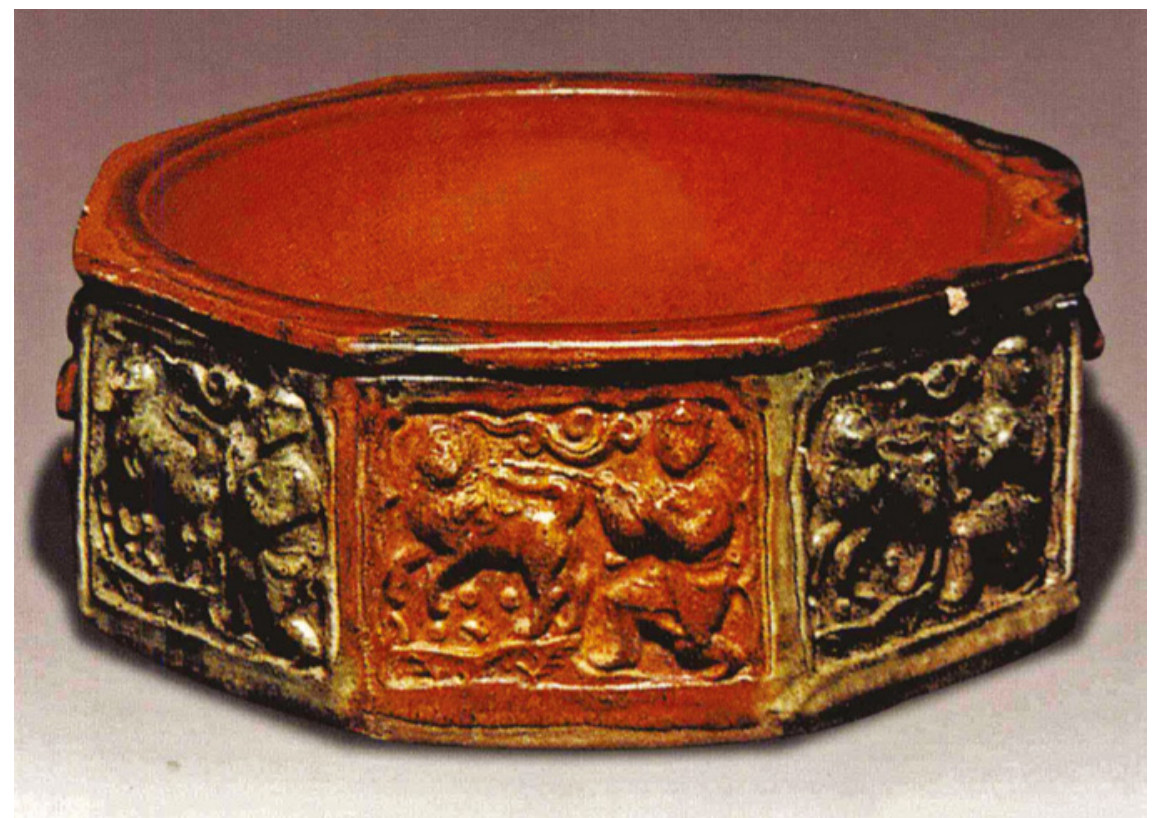

FIgURE 5 Foreign Artist Training a Lion, Three-color Pottery Bowl from the Liao Tomb, Xiaoliuzhangzi Village, Ningcheng

INNER MONGOLIA MUSEUM (AFTER FENG ED. ZHONGGUO TAOCI, FIG. 123, P. 150)

which is now considered an integral part of Chinese culture, was introduced by Central Asians. Unearthed cultural relics from the Liao tombs demonstrate that the Lion Dance was also popular among the Khitans and often performed by artists and acrobats from Central Asia. It also gives the assumption that these foreign artists lived and served at the Liao court.

The Song envoy Wang Yande, who visited Turfan, mentioned that various musical instruments were very popular among the Uyghurs and they took them even when they traveled:

樂多琵琶、筮篌。出貂鼠、白魹、繡文花荵布。俗好騎射。婦人戴油 帽, 謂之蘇幕遮。... 好游賞, 行者必抱樂器。

For music there are many pipa and konghou. They produce sable fur, white fine cotton cloth and floral embroidered fabric. They are fond of horse riding and archery. Women wearyoumao [oil hat] called sumuzhe ... Those, who like to travel and wander surely carry musical instruments. 


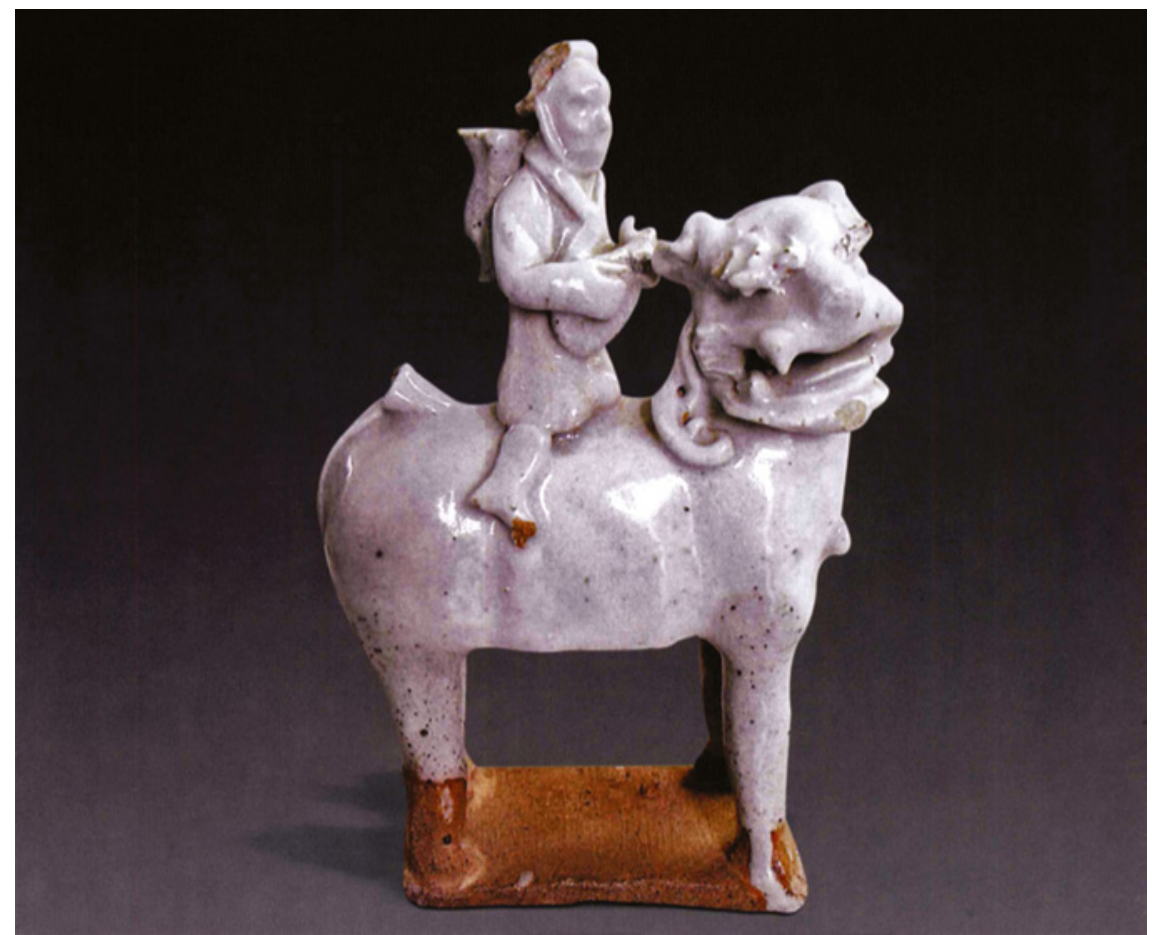

FIgURE 6 Foreign Artist Riding a Lion, Porcelain Statue from the Liao Tomb in Lamagou Village

AOHAN BANNER MUSEUM (AFTER TA AND CHEN ED. ZHONGGUO CHUTU, FIG. 67, P. 67)

One may ask, was it a depiction of contemporary foreigners in the Liao society or duplication of huren images of the previous times? The huren of the Tang period are usually depicted riding horses and camels. Lions mainly appear in hunting scenes in artifacts associated with the Sogdians in China. The images of huren musicians and artists with dancing lions of the Liao period may refer generally to the Uyghurs, particularly to the Xizhou Uyghurs that had most frequent contacts with the Khitans, or to the Qarakhanids, who also had close relations with the Liao dynasty fostered through marriage alliances.

\subsection{Hu Merchants in Song China}

Kaifeng, or as it was known during the Northern Song dynasty, Bianjing, was the biggest, wealthiest, and most advanced city in the world at the time, with about a million residents and a maze of commercial streets filled with bustling activity day and night. Kaifeng's prosperity attracted travelers, monks, scholars and merchants from all over the world. However, in contrast to Tang culture, 
foreign images are not so well presented in Song artifacts, which may give the incorrect impression that foreign trade and contacts were not as important during the Song.

Why did huren images disappear after the Tang? Was it due to the withdrawal of the Sogdians from the Silk Roads or was it just a matter of taste? Overland trade roads continued to be widely used by Uyghur, Tibetan, and Qarakhanid merchants during the Northern Song. Records on the Qarakhanids in Chinese sources mainly contain information on official delegations and caravans sent by the Khagans and do not provide detailed data about their culture and society. The Chinese usually recorded more details on remote peoples and dynasties that were not well known in China. It demonstrates that the Chinese were familiar with the Qarakhanids. Additionally, foreigners from many other remote places of the world also arrived in Song China via the maritime routes, which were even more developed and flourished at that time. During the Song period numerous Muslim merchants from different parts of the world were living in the Chinese port cities. They formed self-controlled enclaves with the permission of the government. ${ }^{8}$ Jewish merchants also lived in these settlements and formed the Kaifeng-Jewish community that has lasted to the present day. ${ }^{9}$ According to the letter from the Qarakhanid Khagan that was presented to Emperor Shenzong in 1081, members of three Qarakhanid delegations that were sent earlier did not come back. ${ }^{10}$ These delegations arrived in China and completed their official missions but for some reason did not return home. It is not known what happened with the members of these delegations. It can be assumed that they decided to settle in China. But this was an exception rather than the rule. The main difference from the Tang period was that foreigners in Kaifeng did not occupy high positions at the Song court. Royal intermarriage was not a common practice either; no sources confirm marriage alliances between the Song emperors and ruling elites of Central Asia. However, the Qarakhanid Khagans, like the Uyghurs and Tibetans, addressed the Song emperors as "maternal uncle" in official correspondence, probably following the protocol that had existed during the Tang. ${ }^{11}$ It is true that exotic foreign cultures and ways of life were deeply admired by the people of the

8 For maritime Muslim merchant communities in Song China, see Chaffee, The Muslim Merchants of Premodern China, 76-123.

9 For the Jewish community in Kaifeng during the Song period, see Donald D. Leslie, "Integration, Assimilation, and Survival of Minorities in China: The Case of the Kaifeng Jews," in From Kaifeng to Shanghai: Jews in China, ed. Roman Malek (Sankt Augustin: Monumenta Serica Institute and the China-Zentrum, 2000), 45-76.

10 Song shi, 490: 14109.

11 Ibid. For the discussion on this issue, see Chapter 2. 
Tang dynasty, which was reflected in their arts. But the complexity of trade networks and international relations along the Silk Roads cannot be judged by the existence of foreign images in Chinese artifacts. At the same time, it would be implausible if the Song passion for foreign commodities and its open foreign policy described in written documents did not leave any signs in material culture. In this section I present some examples of huren images in the Song arts.

A bluish-white porcelain figurine of a foreign merchant pulling a horse that resembles huren, produced during the Tang dynasty, was discovered in a Song tomb in Jingdezhen, Jiangxi Province in 1970 (Figure 7). ${ }^{12}$ Another figurine of a huren with a horse was also found in Leping near Jingdezhen in $1978 .{ }^{13}$ During the Song period, Jingdezhen was famous for the production of Qingbai (bluish-white) ware, which was a transparent, jade-like type of porcelain. Specimens of Qingbai ware were also unearthed from the Qarakhanid capital in Afrasiyab, near Samarqand. ${ }^{14}$

Fragments of Song porcelain have been unearthed in the Tangut realm, which confirms its transportation via continental trade roads to the west. ${ }^{15}$ But it is believed that Song porcelain was mainly exported by sea due to its fragility and complexity of transportation by land. At the same time, the Qarakhanid rulers sent "exquisite Chinese vessels" to the Ghaznavid court as diplomatic gifts. ${ }^{16}$ What if these jewel-like vessels were Song porcelain brought from Jingdezhen? Diplomatic gifts often provide information about highly prized commodities that could be traded in the region. Qarakhanid merchants received cash payment for their goods at the Chinese court. Song coins did not circulate in the Qarakhanid realm; therefore, merchants used their rewards in the Chinese market. They could obtain highly valued Song porcelain along with Chinese silk, silver and tea, and transport it to Central Asia.

Rong Xinjiang has recently raised a question on the possible depiction of caravan merchants in the Song masterpiece Qingming shang he tu (Along the River during the Qingming Festival) painted by the court artist Zhang Zeduan

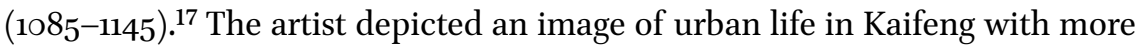

12 Peng Shifan 彭适凡 and Peng Tao 彭涛, “Cong huren qian ma ci song tan Songdai Xiaode zhen ciqi de waixiao 从胡人牵马瓷俑谈宋代景德镇瓷器的外销 [Discussion on the Porcelain Export in Xiaode during the Song Dynasty following a Porcelain Hu man pulling a Horse]," Zhonghua wenhua luntan 中华文化论坛 1 (1995): 68-71.

13 Ibid.

14 Sokolovskaia and Rougeulle, "Stratified Finds of Chinese Porcelains," 91.

15 Kessler, Song Blue and White Porcelain, 23.

16 Kitāb al-Yamin̄i, trans. Reynolds, 317.

17 Qingming shang he tu 清明上河圖 [Along the River during the Qingming Festival], by Zhang Zeduan 張擇端 (1085-1145), retrieved from the Palace Museum Beijing, https:// minghuaji.dpm.org.cn/author/detail?id=7. 


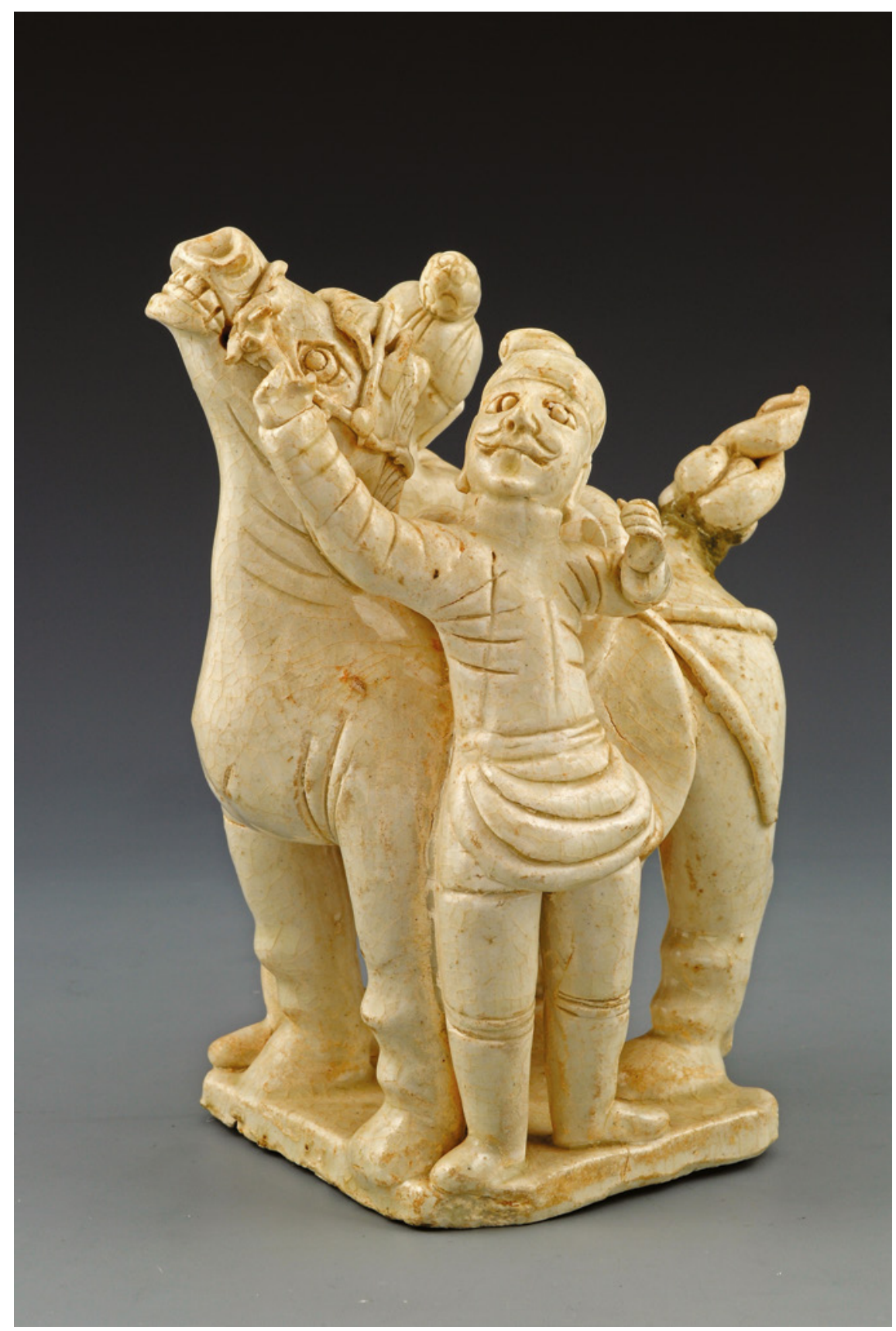

FIGURE 7 Foreign Merchant Pulling a Horse, Qingbai Porcelain Statue from the Song tomb in Jingdezhen

COURTESY OF THE JIANGXI PROVINCIAL MUSEUM 
than 8oo people of different professions and social statuses such as actors, craftsmen, sellers, monks, doctors, teachers, scholars, officials, and many others, including a caravan merchant who is depicted crossing the main city gate pulling a group of camels. The image of the camels laden with heavy bags of commodities evokes foreign caravans going to long-distance places.

Rong Xinjiang pointed out that the merchant wears Chinese-style clothing but has a face with typical huren features such as a high-bridged nose, deepset eyes, and protruding cheekbones, and called him "the only huren on the Qingming shang he tu." ${ }^{18}$ However, Cheng Minsheng assumed that the breeding of camels brought from the Western Regions was also practiced in Kaifeng during the Northern Song period, and thus the merchant could be local. ${ }^{19}$

The image of merchants with camels was always strongly associated with the Silk Road trade and foreigners in China. Therefore, the picture of the merchant leading a camel on the Qingming scroll can be seen as a symbol of the Silk Roads during the Northern Song dynasty. At the same time, it seems strange that the artist did not depict the other foreigners who lived in a cosmopolitan city as Kaifeng. In fact, Zhang Wen suggested another image that may refer to a foreigner on this scroll. He assumed that a person sitting near the sheep market surrounded by a group of people was a Uyghur from the Western Regions. ${ }^{20}$ The person has a long beard, thick eyebrows, fluffy hair and clothing that distinguishes him from the local people.

Zhang Wen suggested that the Qingming scroll was most likely created in the period before 1104, when selling goods and settling in Kaifeng was prohibited for maritime merchants. ${ }^{21}$ It explains why the artist only depicted images of caravan merchants and why there are so few foreigners in the streets and markets of Kaifeng. Moreover, caravan merchants lived and traded mostly in the Xihe Circuit, and arrived in Kaifeng only to offer tribute and receive rewards. The Song emperors even issued edicts to limit the duration of stay at the court

18 Rong Xinjiang 荣新江, “Qingming shang he tu huren xingxiang jiexi《清明上河图》 胡人形象解析 [Analysyis of the Image of a huren on Qingming shang he tu], Xinjiang daily 11, June 23, 2009.

19 Cheng Minsheng 程民, "Qingming shanghe tu zhong de tuodui shi hu shang ma - jian tan Songchao jingnei de fenbu 《清明上河图》中的驼队是胡商吗 - 兼谈宋朝境内 骆驼的分布 [Are the Figures of the Camel Caravan on Qingming shanghe tu Foreign Merchants? Distribution of Camels in Song Territory]," Lishi yangjiu历史研究 05 (2012): 176-82.

20 Zhang Wen 张文, "Ye tan "Qingmimg shanghe tu" zhong de huren ji xiangguan wenti 也谈《清明上河图》中的胡人及相关问题 [Huren and Related Issues in “Qingmimg shanghe tu"]," Suzhou Daxue xuebao (zhexue shehui kexue ban) 苏州大学学报 (哲学社 会科学版) 37 , no. 3 (2016): 169-70.

Ibid, 171-173. 
in Kaifeng for foreign missions. ${ }^{22}$ Therefore, eleventh-century Kaifeng was depicted as a purely Chinese city.

It is easier to find foreign images in paintings related to tributaries of the Song emperors. Song official artists depicted foreign envoys at the court. In fact, during the Song period, a considerable number of artistic works portraying foreign tributary missions appeared. This artistic tradition is known as zhigong tu (portraits of tributaries). The most notable example created during this period is Wanfang zhigong tu (Portrait of Tributaries of the Myriad Regions) by Li Gonglin, which was painted during the rule of Emperor Shenzong in $1079 .{ }^{23}$ It was the period of the Song statesman Wang Anshi's New Policies. The reforms in state finance and trade as increasing the supply of copper coins, improving trade management, and creating the Tea and Horse Agency to buy up Sichuanese tea and trade it to western horse suppliers attracted foreign caravan traders to the Song market. Therefore, Li Gonglin had plenty of opportunities to meet foreigners and accurately represent them in his paintings. The Portrait of Tributaries of the Myriad Regions depicted ten delegations from foreign countries. Each country contains inscriptions by Zeng Yu (1073-1135), which were added during the Southern Song period in 1131. It is important for understanding the names of foreign countries as during the Southern Song period the usage of terms applied to foreign countries in China and their meanings changed. The tributary envoys depicted by Li Gonglin are from Zhancheng (Champa), Boni (Borneo), Chaoxian (Korea), Nüzhi (Jurchens), Fulin (Rum), Sanfoqi (Srivijaya), Nüren guo (the Kingdom of Women), Handong, ${ }^{24}$ Xiyu (Western Regions), and Tubo (Tibet). This artwork has been recently analyzed by Ge Zhaoguang. He assumed that some parts of the painting could be the imagination of the Song dynasty, which sought to represent itself as a universal empire. ${ }^{25}$ At the same time, Song sources recorded frequent missions from most of the countries in this list during Li Gonglin's lifetime. The illustration depicts Chinese international relations along the maritime and continental roads in the eleventh century.

\footnotetext{
22 Song huiyao jigao, Fanyi 4: 18.

23 Wanfang zhigong tu.

24 The location of Handong is unclear. It could have been in Dunhuang or in the Qinghai region.

25 Ge Zhaoguang 葛兆光, "Xiangxiang tianxia diguo - yi chuan Li Gonglin "Wanfang zhigong tu” wei zhongxin 想象天下帝国 - 以(传) 李公麟《万方职贡图》为中心 [An Imaginative Great Empire: Focused on Li Gonglin's Wanfang zhigongtu in the Song Dynasty]," Dan xue bao (Shehui kuxue ban) 旦学报(社会科学版) 6o, no. 3 (2018): 36-48. For the images, see Wanfang zhigong tu.
} 


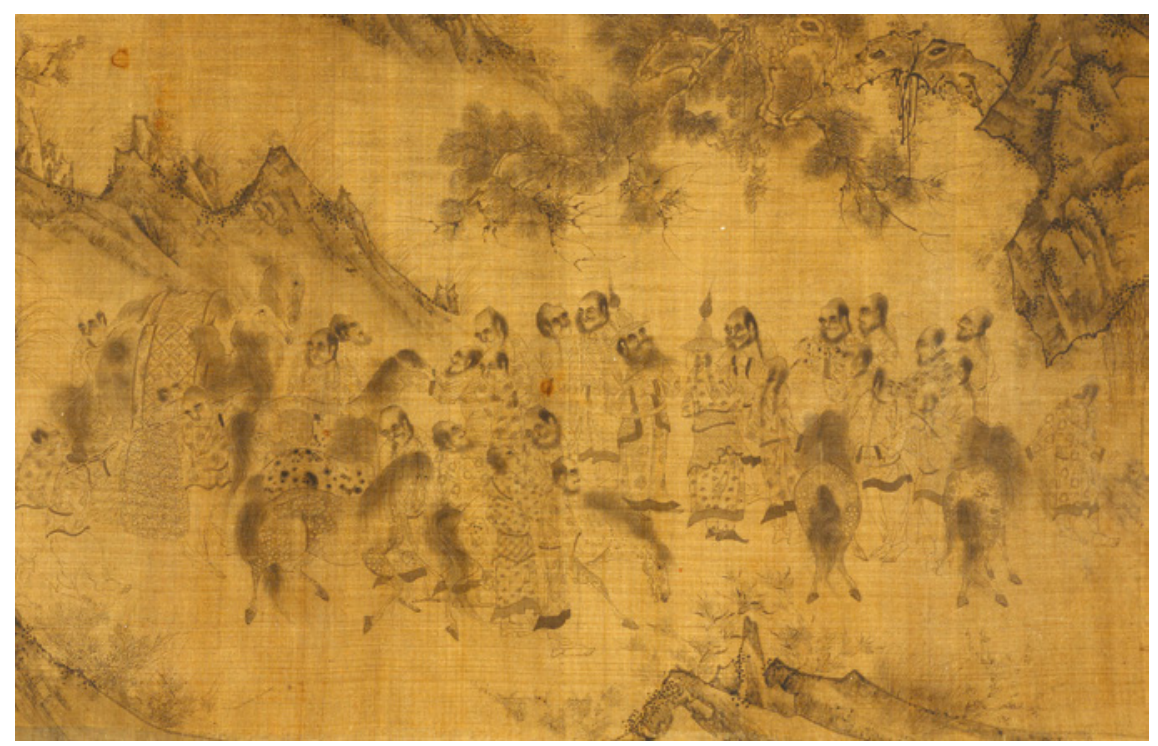

FIGURE 8.1 Envoys from the Western Regions with Camels and Khotan "Floral Horses," from Portrait of Tributaries of the Myriad Regions by Li Gonglin (1049-1106), Freer Gallery of Art, Smithsonian Institution, Washington, D.C., Gift of Charles Lang Freer, F1911.18o, Detail

The portrait of the envoys from the Western Regions contains images of horses and camels (Figure 8.1). It means that this delegation arrived via the land route. The horses should be brought from Khotan, which are known as "floral horses" (huama) due to their spotted coat patterns. Many images of the Khotan "floral horses" dated to the late Tang period were discovered in the Dandan Oilik site. The envoys from Rum were also depicted with horses (Figure 8.2).

Li Gonglin was famous for his horse paintings, including images of Khotan horses. ${ }^{26}$ For instance, he is the author of Wuma tu (Portrait of Five Horses) created in 1090 that depicted Khotan "floral horses," including a groom from Central Asia (Figure 9). ${ }^{27}$ Therefore, it can be assumed that the envoys with

26 For the Khotan huama (floral horses) during the Northern Song period, see Lin Meicun 林 梅村, “Yutian huama kao:jian lun Bei Song yu Yutian zhijian de juan ma maoyi 于阗花马 考: 兼论北宋与于阗之间的绢马贸易 [On Images of the Khotan Horse: Silk and Horse Trade between the Northern Song and Khotan], Xiyu yanjiu西域研究 2 (2008): 44-54.

27 The masterpiece is lost. For the reproduction of all five sections of the masterpiece, see Zhang Anzhi 张安治, Li Gonglin 李公麟 (Beijing: Renmin meishu chubanshe, 1979), 7-12. For the recent full-scale reproduction also, see Itakura Masaaki, Li Gonglin's Scroll Painting Five Horses (Tokyo: Hatori Shoten, 2019). 


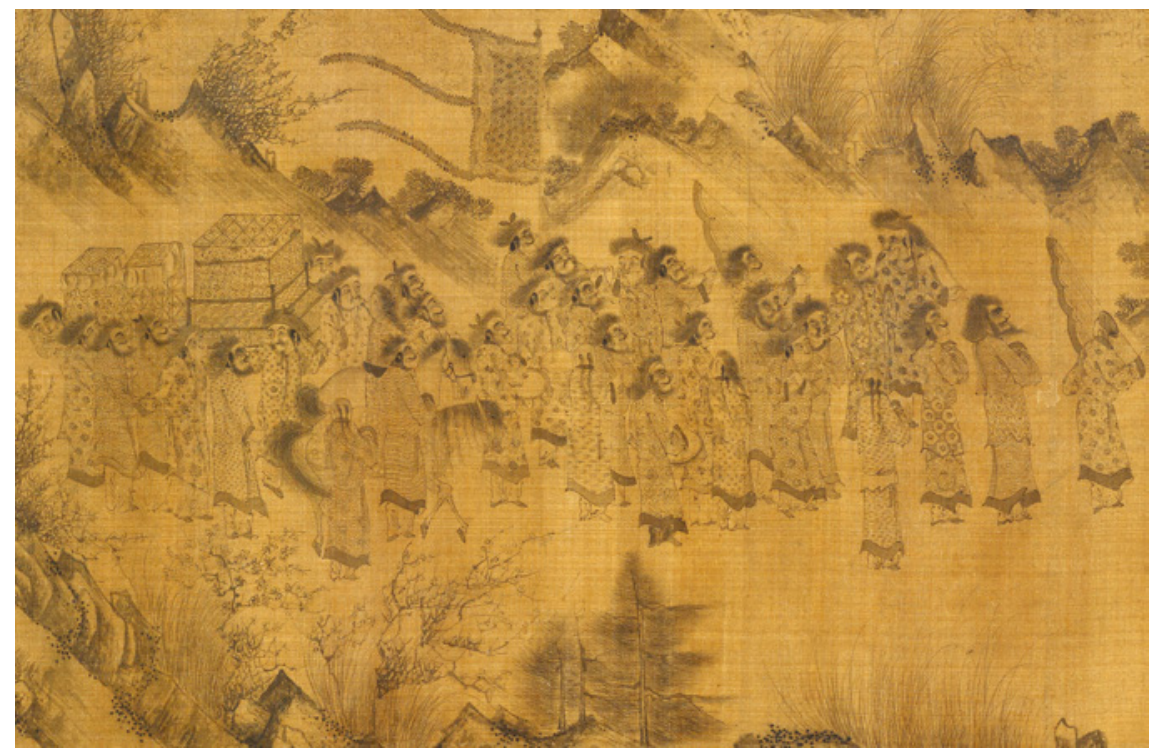

FIGURE 8.2 Envoys from Rum, From Portrait of Tributaries of the Myriad Regions by Li Gonglin (1049-1106), Freer Gallery of Art, Smithsonian Institution, Washington, D.C. Gift of Charles Lang Freer, F1911.18o, Detail

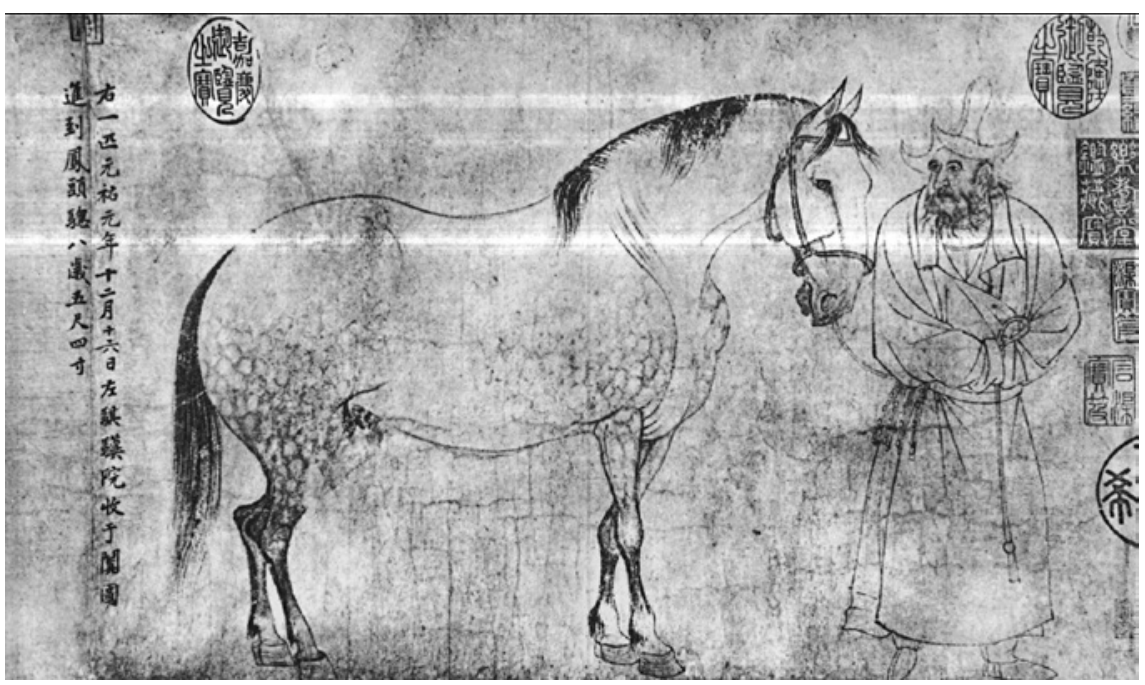

FIGURE 9 Central Asian horseman leading a horse brought from Khotan in 1087, from Portrait of Five Horses by Li Gonglin, 1049-1106, current location is unknown (after Zhang, Li Gonglin, fig. 7, p. 7) 
camels and Khotan "floral horses" painted by Li Gonglin may be the portrait of the Qarakhanid mission.

Besides, foreign images coins are also often viewed as symbols of trade. The next section deals with rare findings of Song coins along the Silk Roads and explains their limited presentation in Central Asia.

\subsection{Song Coins along the Silk Road}

Northern Song coinage circulated through much of Asia, including present-day Japan, Korea, Vietnam and Indonesia. Large hoards of Song coins are still being found in these places. Qarakhanid envoys received mainly cash payments as a reward from the emperor for their commodities. However, compared to East and Southeast Asia, Song coins are rarely found from the territories of the Qarakhanid Khaganate and more generally from Central Asia. For instance, several Northern Song coins were found from a hoard unearthed at the hill fort of Krasnaya Rechka (ancient Nawikath) in 1998. The hoard consisted of three Wu Zhu coins, eight Tang coins and thirty-three Northern Song coins. ${ }^{28}$

Kamyshev also mentioned Northern Song coins from a private collection in Osh that was brought to Bishkek in 2010. This collection contained mainly Northern Song coins but also included five Tang coins and one Southern Song coin dated $1253{ }^{29}$ The exact place where these coins were found is unknown. As far as I know, several Song coins were also found from the Qarakhanid site in Ahsikent (Namangan region, Uzbekistan) in 2010-2011, which are stored in a private collection. Song coins from Osh that were mentioned by Kamyshev could be from Ahsikent. Unfortunately, this data remains unpublished. ${ }^{30}$

When the Qarakhanids converted to Islam they adopted Muslim coinage. Therefore, Chinese coins were not widely circulated in the region after the conversion. Qarakhanid merchants used cash payments received from the emperor to obtain luxury goods in Chinese markets and transported them to Central Asia. For instance, a memorial from the attendant in charge of presents from Qarakhanid Khotan dated March 21, 1064 stated that the envoy Luo Sawen (Boyla Saghun), who received a cash payment, would probably have wanted to receive Chinese commodities instead. ${ }^{31}$ This may explain why hoards of Song coins are so rare in Central Asia.

28 Aleksandr Kamyshev, "Monety Kitaia iz Kyrgyzstana," in Numizmatika Tsentral'noi Azii, ed. Edward Rtveladze (Tashkent, 1999), vol. 4, 6o-61, 64; Aleksandr Kamyshev, Numizmatika Kyrgyzstana (Bishkek, 2014), 67.

29 Kamyshev, Numizmatika Kyrgyzstana, 67.

30 I owe this information to Anvar Atakhodjaev.

$31 \quad$ Song huiyao jigao, Fanyi 7: 31; see Document 5 in Appendix 2. 
If Song coins were not circulated in the region, why did merchants still carry them? A few coins could have remained without any purpose, but some could have been brought as souvenirs or even as relics in later periods. It is known that Northern Song coins were used in ritual burials in Yakutia (Russia) dated no earlier than the twelfth century. ${ }^{32}$ Song coins were also found at the Golden Horde settlements of the fourteenth century in the Volga Region. ${ }^{33}$ It should be noted that the majority of Song coins found in Central Asia and Siberia were minted during the Northern Song period. The main reason is that in the midtwelfth century the Southern Song government started to introduce numerous prohibitions to stop the outflow of copper and replace it with paper money. ${ }^{34}$

This is a short survey of cultural relics from the continental trade in the tenth-twelfth centuries. Indeed, the Chinese of the Song period did not create many artifacts related to foreign cultures when compared to the Tang people, but the disappearance of Sogdian images should not be viewed as the "Silk Road crisis" that continued until the Mongol rule. It should be pointed out that the Northern Song emerged after the rebellion of An Lushan and existed during the rise of the Khitans and Tanguts. These political-military events caused the rise of "ethnicized orthodoxy," as Yang Shaoyun termed the Song interpretation of Chineseness that had a great impact on the representation of foreigners. ${ }^{35}$ In other words, the main reason for the disappearance of foreign images during the Song period and the representation of Kaifeng as a purely Chinese city in Qingming shanghe tu is not due to the "Silk Road crisis" but rather the rise of the new discourses on the Chinese identity and foreign cultures. Moreover, Chinese texts provide crucial data that allows us to speak about "the revival of the Silk Road" during the Qarakhanids. These materials are discussed in the following sections on the Qarakhanid amber and frankincense trade in China.

32 Aleksandr D. Stepanov, "Ritual'nyi klad sunskikh monet," Izvestiia laboratorii drevnikh tekhnologii 1, no. 9 (2012): 147-54.

33 Evgenii M. Pigarev, and Xiaolin Ma, "Nakhodki kitaiskikh monet na zolotoordynskikh gorodischakh Nizhnego Povolzh'ia," Arkheologiia evraziiskikh stepei 6 (2017): 65-8.

34 Angela Schottenhammer, "The Role of Metals and the Impact of the Introduction of Huizi Paper Notes in Quanzhou on the Development of Maritime Trade in the Song Period," in The Emporium of the World: Maritime Quanzhou, 1000-1400, ed. Angela Schottenhammer (Leiden: Brill, 2001), 147-9; Cheng Minsheng 程民生, “Songren shenghuo shuiping ji bizhi kaocha 宋人生活水平及币值考察 [Living Standards and Monetary Value of the Song Dynasty]," Shixue yuekan史学月刊 3 (2008): 107-8.

35 Yang Shao-yun, The Way of the Barbarians: Redrawing Ethnic Boundaries in Tang and Song China (Washington: Washington University Press, 2019), 4. 
Commodity history can offer interesting examples of cultural "migration."36 However, migration history and commodity history are often treated as separate fields. At the same time the trade of luxury goods, from silk to oil, has often been a key driver of international migration. International trade also often caused the migration of ideas and cultures, which moved from one place to another along with tangible commodities. Trade objects in the process of transfer from one place to another brought cultural patterns connected with them, forming new aesthetics and even identities among peoples of other cultures. Thus, material objects from foreign places could become a strong part of the cultures despite not being local or traditional.

Amber in China is one of the best examples of cultural migration and the "traveling" of aesthetics in history that was transferred to China along the Amber Road from Europe. However, the "Chinese passage" of the Amber Road has received less attention in recent scholarship. Amber has been transported to China via international trade networks since ancient times and is deeply integrated into Chinese culture. Amber markets can still be found all over China and it is truly considered a symbol of the country. Amber used in present-day China also comes from Fushun, Liaoning Province in Northeast China. The mining district in the Fushun basin that was found around a century ago is closing, ending the supply of domestic amber. However, this region was never recorded in Chinese histories as a source of amber. Amber was usually mentioned in ancient Chinese sources among products of the Western Regions and the "southern barbarians" and was transferred to China along international trade roads.

The most studied amber-bearing locations in Eurasia stretch from the shores of the North Sea up to the Black Sea. When discussing the ancient Amber Road, scholars usually refer to trade networks used for the transfer of amber from the North Sea and the Baltic Sea to the Mediterranean region. At the same time, recent discoveries of Baltic amber in more distant territories have prompted a fresh look at the issue in the scholarship. ${ }^{37}$

36 The materials used in this section were initially published in: Dilnoza Duturaeva, "The Amber Road to China: Trade and Migration of Culture in Pre-Modern Eurasia," in Migration and Identity in Eurasia from the Ancient Times to the Middle Ages, ed. Victor Cojocaru and Annamária-Izabella Pázsint (Cluj-Napoca: Editura Mega, 2021), 251-267. literatura, 2001), 124-35; Kashani N. Bagherpour, and Thomas Stöllner, "Iron Age Amber Beads from Vešnave/Iran," Archäologische Mitteilungen aus Iran und Turan 43 (2011): 71-8; 
The Amber Road was much more complex than a simple connection of the northern and southern parts of Eurasia. Central Asian and Chinese written sources report that amber was transferred from Europe to remote areas of Asia by overland routes. Using infrared spectroscopy, archaeologists have also confirmed the movement of amber from Europe, more precisely from the Baltic region, to Central Asia and China.

\subsection{Baltic Amber in Central Asia}

No natural sources of amber have been found in Central Asia. However, amber items are found throughout the entire territory from the Bronze Age to the fourteenth century. Therefore, it can be concluded that amber arrived in Central Asia via trade routes. The most ancient sample discovered so far was found in the Bronze Age settlements Zaman-Baba and Gujayli located in the Bukhara Oasis (present-day Uzbekistan). ${ }^{38}$

If amber was brought to Central Asia by trade, where did it originate from? The main sources of amber in Eurasia are found along the Baltic and North Sea coasts. General archaeological research on amber items found in various parts of Central Asia has been done by Bubnova and Polovnikova. The authors collected relevant data from scholarly publications and unpublished materials in museums and archaeological collections. As they pointed out, relevant publications on amber items found in archaeological monuments in Central Asia provide precious little information about their origin. Therefore, the authors examined 68 amber items collected during their research using infrared spectroscopy. These items belonged to different historical periods. The analysis demonstrated that most of the items originated in the Baltic region. ${ }^{39}$

Archaeological evidence indicates that amber was actively traded in Central Asia, particularly from the middle of the first millennium BCE to the fifth century CE. From this period onward, amber appeared in Caucasia and Iran, where no natural sources of amber are known either. Amber was well-known and widely traded in the entire territory of Caucasia. The recent infrared spectroscopic analyses of amber items from the Kichmalka II burial

David Braund, "Nero's Amber-Expedition in Context: Connectivity between the Baltic, Black Sea, Adriatic and India from Herodotus to the Roman Empire," in Interconnectivity in the Mediterranean and Pontic World, ed. Victor Cojocaru, Altay Coşkun, and Mădălina Dana (Cluj-Napoca: Mega Publishing House, 2014), 435-56.

38 Makhsuma Niyazova, Drevnie i srednevekovye iuvelirnye izdeliia kak istochnik ob istorii kul'tury Bukhary (po arkheologicheskim materialam), Avtoreferat dissertatsii na soiskanie stepeni kandidata istoricheskikh nauk (Samarkand: Academy of Sciences of Uzbekistan, 2007), 7 .

Bubnova, and Polovnikova, "Iantar' v Srednei Azii," 124-135. 
ground (Kabardino-Balkaria), which is known as the richest amber finding in the region, unsurprisingly indicated the Baltic origin of all samples. ${ }^{40}$ Amber was probably further transported from Caucasia to Iran. The most interesting samples of amber in Iran were found in the Veshnave copper mine near Qom. Sixty-two amber beads and three pendants were found in this location in the area that dates to the period between the late Iron Age and the Sassanian Era. Infrared spectroscopy proved that these items were imported from the Baltic region. Moreover, several amber items were similar to the bag-shaped amber beads produced in Europe. This indicates that amber was transported to remote territories not only as raw material but also as finished jewelry. ${ }^{41}$

The amber trade connected the Baltic region with the Eastern Mediterranean starting in the middle of the second millennium BCE. This route may have later been connected with the Silk Roads and used for the amber transfer to Central Asia. At the same time, there were other networks used for the amber transfer to Central Asia. Archaeological analysis of amber items found in Central Asia demonstrated the importance of Khwarazm as the main transit point of the Baltic amber to the region. ${ }^{42}$ The same statement can be done based on medieval Muslim written sources, which recorded that amber was transported from the Volga Region to Khwarazm, from whence it reached Transoxiana and other territories in the Islamic world. For instance, a tenth-century Arab geographer and traveler, al-Muqaddasī, enumerated a rich list of items transported by merchants of Volga Bulgharia to Khwarazm, including amber. ${ }^{43}$

Amber was generally known as a commodity from the Bulghar and the Slavonic regions in medieval Central Asia. For instance, al-Bīrūnī pointed out that amber was known as "as the dew that falls on the mountains in Bulgharia (jabāl bi-Bulghār)." ${ }^{\prime 4}$ Marwazī, a Central Asian physician who served at the Saljuq court, mentioned that amber derived from the seas of Șaqāliba, meaning

40 Elena E. Vasileva, "Iantar' v skifskoe vremia na Kavkaze," in Iantar'v drevnikh kul'turakh: Khudozhestvennye proizvedeniia iz sobraniia Ermitazha, ed. Olga Fedoseenko (Saint Petersburg: Slaviia, 2010), 25-34.

41 Bagherpour, and Stöllner, "Iron Age Amber Beads," 71-78.

42 For the discussion on archaeological evidence, see Bubnova, and Polovnikova, "Iantar' v Srednei Azii," 126.

43 Kitāb ahsān al-taqāsìm fì márifat al-aqālìm, ed. Goeje, 324-325. Also compare with the English translation Kitāb ahsān al-taqāsìm fì márifat al-aqālèm, trans. Collins, 286.

44 This information is given in the description of amber (kahrubāy, kārubā) in the manuscript copy translated by Karimov, see Kitāb al-șaydana fi al-țībb, trans. Karimov, 776 . The description of amber in the manuscript edited and translated by Said is shorter and this information is not recorded, see Kitāb al-șaydana fi al-țībb, ed. and trans. Said, 284-285, for the Arabic text, see $324-325$. This passage is recorded in the text edited by Abbas Zaryab, see Kitāb al-șaydana fì al-țîbb, ed. Zaryab, 548 . 
the Slavonic lands. ${ }^{45}$ It should be noted that the term Șaqāliba, meaning "Slavs," could be used by Muslim authors to refer to Central and Eastern Europeans in the medieval period, including the Volga Bulghars.

Among the imported commodities from Khwarazm into the Islamic world are items not only from the Volga Bulghars but also from the Vikings, who actively traded in Bulghar markets. ${ }^{46}$ Furs, as well as slaves, were the main commodities from the North exported for dirhams and other luxury items from the Islamic world, India, and China. Baltic amber was also among these precious commodities from the North.

Trade with Northern Europe continued during the Qarakhanid period. The Vikings shipped various goods from their realm to the Volga Bulghars to obtain commodities from the Islamic world, including fabrics produced in Central Asia that are found in Viking burials. ${ }^{47}$ Northern and Eastern Europe are also referred to as Rūs, Varang, and Șaqāliba on the map of the Turks and their neighbors that appeared in Dīwān lughāt al-Turk. ${ }^{48}$ From these and other Muslim written sources, it becomes clear that Bulghar merchants played a significant role in trade between Central Asia and Europe in the tenth and eleventh centuries. The Volga Bulghars traded in Khwarazm, bringing commodities from the Vikings' world. From Khwarazm, these items were transported to the Qarakhanid realm. However, Bulghar merchants could also pass farther, to the Qarakhanid realm. ${ }^{49}$ Therefore, it can be assumed that Qarakhanid merchants could also trade in Volga Bulgharia, and if so, they could directly obtain products from the Vikings, including Baltic amber. Chinese sources indicated that the Qarakhanids were the main supplier of amber to China in the eleventh century. This explains why the Qarakhanids prized amber and sought to acquire it: it was valuable for trade with China.

Mapping of the amber items in Central Asia by Bubnova and Polovnikova illustrates that amber was circulated within the region mainly in two directions: along the Syr Darya and the Amu Darya. According to the authors, the Syr Darya road was used for the transportation of amber via Ferghana to China. ${ }^{50}$ It is difficult to determine when exactly Baltic amber began to be transported to China. To the best of our knowledge, Baltic amber appeared in Siberia starting in the seventh century вСЕ. A rich cache of Baltic amber items dated to this period has recently been discovered in Arzhan, a site of early Skythian

Țabā'i ${ }^{\prime}$ al-hayawān, ed. and trans. Minorsky, 16-17.

46 Risāla / Faḍlān, trans. Lunde and Stone, 45-47.

47 For Central Asian fabrics found from the Vikings' burials, see Vedeler, Silkfor the Vikings.

48 Dìwān lughāt al-Turk, trans. Auezova, 1289-9o.

49 Ibid, 316, 2529.

50 Bubnova, and Polovnikova, "Iantar' v Srednei Azii," 125. 
kurgan burials, located in Tuva Republic, Siberia. These items are currently the easternmost findings of Baltic amber from this period. ${ }^{51}$

Amber in Caucasia and Central Asia are mainly found in kurgans of the Skythian period, when the Skythians extended their influence across the Eurasian steppe from the western borders of China to the northern Black Sea during the seventh-third centuries BCE. Archaeological data demonstrates that there was a high demand for amber among the Skythian elites, probably as a sign of power and nobility. The Skythians played a significant role in the international trade networks connecting the Mediterranean region with Central Asia, Iran, and China. As a result of migration and cultural contact along the trade routes, amber became common and fashionable in the region. The amber trade continued in Central Asia in the post-Skythian period; however, amber is poorly preserved in the region, especially after the ninth century. At the same time, written sources indicate that the amber trade continued and flourished in the tenth and eleventh centuries, especially under Qarakhanid rule. The lack of archaeological findings can be explained by Islamic burial traditions and therefore most amber items of this period were found only in settlements. At the same time, both Central Asian and Chinese sources confirm that there was a high demand for amber at the Qarakhanid court as well as in Liao and Song China.

\subsection{Baltic Amber in China}

China has the richest history of amber use outside of Europe. Once a symbol of luxury and power in China, amber is still used nowadays for jewelry as well as in traditional medicine. Chinese miners recently found a native deposit of amber in Fushun, Liaoning Province; however, as mentioned above, this source of amber was not recorded in historical sources.

Baltic amber was identified among amber objects of different historical periods from East Asia, mostly from China, with a few from Korea and Japan, which are stored at the Metropolitan Museum of Art. The collection also includes other sources of amber that require further investigation. ${ }^{52}$ The question arises: how and from what sources did the Chinese obtain their amber? The earliest record of amber in Chinese sources appeared during the Former

51 Konstantin V. Chugunov, "Iantar' sredi zolota kochevnicheskikh vladyk. Tsar'skii kurgan ranneskifskogo vremeni Arzhan-2 v Tuve," in Iantar' $v$ drevnikh kul'turakh: Khudozhestvennye proizvedeniia iz sobraniia Ermitazha, ed. Olga Fedoseenko (Saint Petersburg: Slaviia, 2010), 47-54.

52 Lin Yingchun Linda 林盈君 and Adriana Rizzo, "Conservation of amber at the Metropolitan Museum of Art, New York, USA: Regalrez" 1126 as a consolidant and adhesive for amber and copal," Studies in Conservation 59.1 (2014): 100. 
Han period. Amber was described as a local product of Jibin, a polity located in present-day Afghanistan..$^{53}$ Archaeological records also confirm that amber appeared in China in the form of amulets and jewelry from the second-first centuries BCE. ${ }^{54}$ From the Late Han period, amber was listed among products of the Ailao people who lived in the region of modern Yunnan Province of China, northwest Vietnam, northern Laos, and northern Myanmar. ${ }^{55}$ This information refers to Burmese amber. At the same time, amber was also recorded among commodities of the Roman Empire. This amber could be from the Baltic region or brought from Burma, if the Romans traveled by sea:

土多金银奇宝, 有夜光璧、明月珠、骇鸡犀、珊瑚、虎魄、琉璃、琅 玕、朱丹、青碧。56

In the land [of Daqin, i.e. the Roman Empire] there are a lot of gold, silver and incredible treasures, there are night-blooming jade [i.e. pearls], bright-moon pearls, haijixi, ${ }^{57}$ coral, amber, glass, pearl-like stone [white carnelian], red cinnabar and bluish green jade.

The Chinese word for amber in ancient written sources is hupo, also wupo or shoupo. Pulleyblank pointed out that the word hupo may represent Greek ¿ $\rho \pi \alpha \xi$ "amber."58 Laufer assumed that the word derived from the Tai languages of Yunnan, which was the main trading post of Burmese amber. ${ }^{59}$ Both Baltic and Burmese amber were well-known in China during the Later Han period. Trade between Han China and the Roman Empire was carried on by the Parthians in the initial stage and Baltic amber was probably introduced to China by the Parthian merchants. For instance, Hou Hanshu recorded that the Parthians sought to control the trade routes with China and the Romans as the Romans did not have direct relations with China until the first envoy was sent to the Han court in $166 \mathrm{CE} .^{60}$

\footnotetext{
53 Han shu, 96: 3885.

54 Jenny F. So, "Scented Trails: Amber as Aromatic in Medieval China," Journal of the Royal Asiatic Society 23, no. 1 (2013): 88-9.

55 Hou Han shu, 86: 2849 .

56 Hou Han shu, 88: 2919.

57 Haijisi: the term for rhino horn, literally "rhino horn that frightens chickens."

$5^{8}$ Edwin G. Pulleyblank, "The Consonantal System of Old Chinese," Asia Major 9 (1962): 124.

59 Laufer, Sino-Iranica, 523.

6o Hou Hanshu, 88: 2919-2920.
} 
It is difficult to prove amber transfer to China via Khwarazm and Transoxiana during the Han period. This road seems to be more widely used from the fourth century. For instance, Khwarazm appeared in Chinese sources of this period as an "amber land":

呼似密國, 都呼似密城, 在阿弗太汗西, 去代二萬四千七百里。土 平，出銀、琥珀，有師子，多五果。61

The Hushimi [Khwarazm] state and its capital the Hushimi city are located at the north of Afutaihan; it is 24,700 li away from the Dai. ${ }^{62}$ The land is peaceful, it exports silver and amber, and there are lions and many fruits of five kinds [peach, plum, apricot, chestnut, jujube].

During the Sui and Tang periods, amber transportation from Khwarazm to the East was most likely controlled by Sogdian merchants, who played a significant role in trade between Central Asia and China from the second century BCE up to the tenth century CE, especially in the fifth and sixth centuries. ${ }^{63}$ The Baltic amber that arrived via Khwarazm to Transoxiana may have been transported by the Sogdians along the Syr Darya, then to China and other parts of East Asia. For instance, the archaeological analysis of amber from the Shosōin treasure house located in Nara, Japan and dated to the eighth century confirms its Baltic origin. ${ }^{64}$ The contributions of written sources are for this part very scattered. Chinese chronicles recorded amber among the products of Persia (Bosi). ${ }^{65}$ The term "Bosi" mainly referred to the Sassanian Empire in Iran, but it can also be used for Sogdia in Central Asia.

The Sogdians are considered the earliest and the most numerous migrants into China from western lands. The image of "Persia" and "Persian" products was mediated largely by the Sogdians at the Chinese court rather by the Sassanians. The latter had infrequent contacts with China compared to the Sogdians. Therefore, amber, which was considered a "Persian" product during the Sui-Tang period, was most likely transported by the Sogdians from Central Asia.

During the Tang period, amber was also recorded as a product from the lands of the "Southern Barbarians" or the Huanwang country in present-day

$61 \quad$ Bei shi, 97:3224.

62 Dai was a state, existed in northern Hebei during the Spring and Autumn Period.

63 For more details on the Sogdian traders and their trade with China, see de la Vaissiere, Sogdian traders.

64 For Baltic amber in Japan, see de la Vaissiere, Sogdian traders, 253.

65 Nan shi, 79: 1986; Sui shu, 83: 1857. 


\begin{tabular}{|c|c|c|c|}
\hline & Period & Origin & Remarks \\
\hline 1. & Former Han & Jibin $^{\mathrm{a}}$ & HS 96: 3885 \\
\hline 2. & Later Han & Ailao $^{\mathrm{b}}$ & HHS 86: 2849 \\
\hline 3. & Later Han & The Roman Empire & HHS 88: 2919 \\
\hline 4. & $\begin{array}{l}\text { Northern and } \\
\text { Southern Dynasties }\end{array}$ & Byzantium & BS 97: 3224 \\
\hline 5. & $\begin{array}{l}\text { Northern and } \\
\text { Southern Dynasties }\end{array}$ & Khwarazm & BS 97: 3224 \\
\hline 6. & $\begin{array}{l}\text { Northern and } \\
\text { Southern Dynasties }\end{array}$ & Persia & $\begin{array}{l}\text { The word "amber" was } \\
\text { written as wupo }\end{array}$ \\
\hline 7. & Sui & Persia & $\begin{array}{l}\text { NS 79: } 1986 ; \text { BS } 97: 3^{222} \\
\text { The word "amber" was } \\
\text { written as shoupo }\end{array}$ \\
\hline 8. & Tang & Japan & $\begin{array}{l}\text { ss } 83.1857 \\
\text { As big as } 1 \text { dou } \\
\text { XTS 220: } 6208 \text {; JTS 4: } 73\end{array}$ \\
\hline 9. & Tang & Byzantium & $X T S$ 221: 6261 \\
\hline 10. & Tang & Nanping $\mathrm{Lao}^{\mathrm{c}}$ & XTS 222: $6328-6329$ \\
\hline
\end{tabular}

a Jibin, an ancient country located in present-day Afghanistan.

b Ailao located in modern Yunnan province of China, northwest Vietnam, northern Laos and northern Myanmar.

c Nanping Lao located in present-day Sichuan, Guizhou and Yunnan.

Vietnam and from the territory of Fulin, which refers to Byzantium. ${ }^{66}$ Amber did not often appear as a diplomatic gift at the Tang court. Chinese histories did, however, record information about an envoy from Japan who presented an amber item to the Chinese Emperor in $655 .{ }^{67}$

Unlike previous periods, amber became extremely popular in China at both the Song and the Liao courts in the tenth and eleventh centuries, which can be confirmed by written and archaeological sources. Chinese official histories that recorded commodities from foreign rulers brought to the court as a tribute can also give information about objects traded in China. For instance, amber

66 Xin Tang shu, 221: 6261; 222.6297.

67 Ibid, 220: 6208; Jiu Tang shu, 4: 73 . 
used as decoration for imperial clothing at the Northern Song court arrived in China from the Western Regions. ${ }^{6}$

Initially, amber was brought mainly by the Uyghur polities located in the Hexi Corridor, the main passage of the Silk Roads that connected China with Central Asia. Obviously, the Uyghurs had access to amber through the trade with the Qarakhanids. Later, the amber trade in China was carried out directly by the Qarakhanids themselves. Chinese records demonstrate that compared to earlier periods, there was a high demand for amber at the Northern Song court (See Tables 4 and 5).

The passion for amber among the Song elites could be adopted from the Khitans, their northern neighbors and the founders of the non-Han Chinese Liao dynasty. In fact, no other previous Chinese dynasty prized amber as much as the Liao. Infrared spectroscopy testing of amber items found in Liao tombs demonstrated that these were made of amber from the Baltic region. ${ }^{69}$ According to Marwazī, the Khitans prized amber because they believed it to be helpful against the evil eye, and they preferred to import Slavic amber due to its higher quality than the local supply. Marwazi claimed that the "local amber" was blackish and there was no demand for it. ${ }^{70} \mathrm{He}$ was probably referring to Burmese amber that was transported to the Liao realm from Song China.

TABLE 6 Amber trade during the Northern Song

\begin{tabular}{|c|c|c|c|}
\hline & Date & Envoy & Quantity \\
\hline 1 & $\begin{array}{l}\text { January } 12,962 \\
(s H Y: F Y 7: 1)\end{array}$ & The Uyghurs & not specified \\
\hline 2 & $\begin{array}{l}964 \\
(s H Y: F Y 4: 1 ; \\
\text { SS 490: 14114) }\end{array}$ & The Uyghurs & 40jin \\
\hline 3 & $\begin{array}{l}\text { May-June, } 965 \\
(\text { sHY: FY 4:1) }\end{array}$ & The Uyghurs & $229 j i n$ \\
\hline 4 & $\begin{array}{l}\text { December 2, } 965 \\
(s H Y: F Y 4: 2 ; 7: 3 \\
\text { ss 490: } 14110)\end{array}$ & $\begin{array}{l}\text { Xizhou Uyghurs } \\
\text { (Turfan) }\end{array}$ & a cup \\
\hline
\end{tabular}

68 For amber as a decoration of Imperial dresses, see Xu zizhi tongjian changbian, 206: 4992, 4994.

69 Shen, Schätze der Liao, 110-111, 152-153, 166-173, 182-183, 186-187.

70 Țabā’i' al-hayawān, ed. and trans. Minorsky, 16-17. 
TABLE 6 Amber trade during the Northern Song (cont.)

\begin{tabular}{|c|c|c|c|}
\hline & Date & Envoy & Quantity \\
\hline 5 & $\begin{array}{l}\text { December } 26,965 \\
(s s 2: 23)\end{array}$ & $\begin{array}{l}\text { The Ganzhou Uyghurs } \\
\text { and Khotan }\end{array}$ & 500 jin \\
\hline 6 & $\begin{array}{l}\text { January 6, } 966 \\
(s H Y: F Y \text { 4: } 2 ; 7: 3 ; \\
s s \text { 490: 14114) }\end{array}$ & $\begin{array}{l}\text { The Ganzhou } \\
\text { Uyghurs together with } \\
\text { Shazhou, Guazhou } \\
\text { and Khotan }\end{array}$ & 5ojin \\
\hline 7 & $\begin{array}{l}\text { April 13, } 980 \\
(\text { sHY: } F Y 4: 2,7: 10)\end{array}$ & $\begin{array}{l}\text { The Ganzhou and } \\
\text { Shazhou Uyghurs }\end{array}$ & not specified \\
\hline 8 & $\begin{array}{l}988 \\
(s H Y: F Y 7: 12)\end{array}$ & Srivijaya & not specified \\
\hline 9 & $\begin{array}{l}\text { February-March, } 1010 \\
\text { (sHY: FY 4: 14; } \\
\text { ss 490: } 14116\end{array}$ & Kucha & $40 j i n$ and $45 j i n$ \\
\hline 10 & $\begin{array}{l}\text { October } 30,1010 \\
(s H Y: F Y 2: 4)\end{array}$ & The Khitans & not specified \\
\hline 11 & $\begin{array}{l}1011-1012 \\
(s s \text { 490: 14121) }\end{array}$ & Dashi & not specified \\
\hline 12 & $\begin{array}{l}\text { July } 1022 \\
(S H Y: F Y 2: 12)\end{array}$ & The Khitans & not specified \\
\hline 13 & $\begin{array}{l}\text { April 13, } 1025 \\
(s H Y: F Y 7: 23)\end{array}$ & The Ganzhou Uyghurs & not specified \\
\hline 14 & $\begin{array}{l}\text { March 13, } 1028 \\
(\text { sHY: FY 7:23) }\end{array}$ & The Ganzhou Uyghurs & not specified \\
\hline 15 & $\begin{array}{l}\text { January } 27,1037 \\
(s H Y: F Y 7: 25)\end{array}$ & The Shazhou Uyghurs & not specified \\
\hline 16 & $\begin{array}{l}\text { March 18, } 1071 \\
(s H Y: F Y 7: 32)\end{array}$ & The Qarakhanids & not specified \\
\hline 17 & $\begin{array}{l}\text { December 4, } 1072 \\
(s H Y: F Y 7: 33 \\
s s \text { 491: 14137) }\end{array}$ & Japan & beads \\
\hline 18 & $\begin{array}{l}\text { March 3, } 1074 \\
(s H Y: F Y 7: 33)\end{array}$ & The Qarakhanids & not specified \\
\hline 19 & $\begin{array}{l}\text { May 2, } 1077 \\
(\text { sHY: } F Y 7: 33)\end{array}$ & The Qarakhanids & not specified \\
\hline
\end{tabular}


According to Qidan guo zhi, amber was a common diplomatic gift to the Liao Emperor presented by envoys from the Qarakhanid and Uyghur territories. ${ }^{71}$ Amber was also brought to Liao China for trade. Numerous amber objects such as beads, earrings, and amulets from the tomb of the Liao Princess of Chen and her husband demonstrate that these items were made in the Liao realm; thus, it can be concluded that the Qarakhanids transported to China mainly raw materials. It can be also observed from the table on the amber trade in the Northern Song.

It is difficult to explain why amber became so popular at the Liao and Northern Song courts. Central Asian merchants were aware of the high demand for amber in China. It was believed that the Chinese, particularly the Khitans, prized amber for its purported evil-averting properties. ${ }^{72}$ The demand caused a flourishing amber trade in China from the tenth to the twelfth centuries that stopped after the fall of the Liao Empire. Was this because the continental trade routes were reduced in the twelfth century due to the conflict between the Jurchens in North China and the Khitans who had to migrate to Central Asia and found the Qara Khitai Empire in the new region? Or was it because "amber fashion" simply left China with the Khitans? Nevertheless, amber continued to be circulated in China and viewed as a commodity from western lands during the Ming dynasty. For instance, it was mentioned as a commodity from Holland and Timurid Central Asia. ${ }^{73}$ Amber was also among the diplomatic gifts presented by the Ottomans to the Ming Emperor. ${ }^{74}$ The interesting thing is that amber fashion was reintroduced into Chinese culture again by the nonHan northern people during the Qing period. In the present day, it is nearly impossible not to consider amber a fully localized cultural object of China.

To sum up, the Amber Road that connected Northern Europe with the Mediterranean region reached Caucasia and Central Asia by the late Bronze Age and flourished from then on, especially during the Skythian period, when "amber fashion" was introduced to the region. Amber was transferred to Central Asia and then to China from the Mediterranean, and also from Eastern Europe via the Volga Region. Khwarazm served as the main point used for the amber transfer from the Volga Region to Central Asia. According to archaeological data, amber was further transported, mainly by means of river routes along the

71 Amber appeared in the list of diplomatic gifts presented by the joint delegations from the Qarakhanid and Uyghur polities that arrived once in three years, Qidan guo zhi, 21: 205. For the list of gifts, see Chapter 2.

72 Kitāab al-ṣaydana fi al-țībb, ed. and trans. Said, 285, Arabic text 325; Ṭabā’‘ al-ḥayawān, ed. and trans. Minorsky, 17 .

73 Ming shi, 325: 8437; 332: 8612.

74 Ming shi, 332: 8627. 
Amu Darya and the Syr Darya. The Syr Darya road was used for amber transfer via Ferghana to China. Alternatively, amber also reached China via Siberia, where it was known starting from the seventh century BCE. Chinese sources, however, begin to mention amber during the Former Han period, roughly from the second century ВСE. Archaeological evidence also confirms the circulation of amber during this period in China.

From the Han to the Tang periods in China, amber was known mainly as a commodity from the southern territories and the Mediterranean region. Amber was not a common trade commodity in China during this period and was presented mainly as a diplomatic gift, or so we may assume based on Chinese official histories. The situation changed during the Northern Song period from the tenth to twelfth century in China, when amber began arriving in large quantities. Amber became very fashionable at the Chinese court and was widely used for jewelry and decorating imperial dress. The high demand for Baltic amber, which was (and still is) prized for its quality, prompted the flow of this commodity into China along the continental trade routes during the tenth-twelfth centuries. The Qarakhanids became the main suppliers of Baltic amber to the East. Therefore, by the time of the Northern Song court, amber was no longer associated exclusively with the Romans or the Byzantines. The Chinese were well informed about the exact origin of Baltic amber that was presented by merchants traded in China. It was probably starting in the Song period that amber became a strong part of the Chinese culture and has remained so until the present day. China is still the biggest market for Baltic amber.

Frankincense is an aromatic resin that has been widely traded along the ancient trade roads collectively known among modern historians as the Incense Road. It is not "French incense," as may be assumed from its name. Frankincense is produced from varieties of trees of the genus Boswellia that grow in South Arabia, East Africa and some parts of India. The purest frankincense, both during ancient times and now, comes from South Arabia. It was a key product imported by merchants from Arabia to the Mediterranean region, India, Southeast and East Asia in the pre-modern world. Therefore, it is also known as olibanum that derived from the Arabic word al-lubān meaning "milk" due to its milky color. The Chinese also called it "milky incense" (ruxiang); another term was xunluxiang, which was derived from its Persian name kundur. It indicates that the product was also brought and made known to China by Persian merchants. 
The overland trade in drugs and aromatics between South Arabia, the ancient Near East, Greece and Rome began at the start of the first millennium вCE. Frankincense was widely used in drugs and medicines and highly prized in ancient China starting in the Han period. It was most likely first transported from the Mediterranean region, as the Chinese recorded frankincense as incense produced in the Roman Empire. ${ }^{75}$ The incense trade flourished between Arabia and the Mediterranean region during the Romans from the second century BCE to the second century CE. The Roman Empire became a center of the incense trade and consumption of aromatics. The Romans considered frankincense to be a symbol of wealth, prestige and religion. ${ }^{76}$

TABLE 7 The maritime frankincense trade during the Northern Song

\begin{tabular}{|c|c|c|c|}
\hline & Date & Origin & Quantity \\
\hline 1. & $\begin{array}{l}961 \\
(s s \text { 489: 14079) }\end{array}$ & Champa & 10oojin \\
\hline 2. & $\begin{array}{l}962 \\
(s H Y: F Y 4: 63)\end{array}$ & Champa & 1200 jin \\
\hline 3. & $\begin{array}{l}964 \\
(s s \text { 1: 16) }\end{array}$ & Quanzhou $^{\mathrm{a}}$ & unspecified \\
\hline 4. & $\begin{array}{l}966 \\
(s H Y: F Y 4: 63)\end{array}$ & Champa & 3ojin \\
\hline 5 . & $\begin{array}{l}972 \\
(s s \text { 489: 14089) }\end{array}$ & Srivijaya & unspecified \\
\hline 6. & $\begin{array}{l}977 \\
(\text { sHY: FY 7:7-9) }\end{array}$ & Quanzhou & $\begin{array}{l}103,000 \text { jin in total } \\
\text { during the year }\end{array}$ \\
\hline 7 . & $\begin{array}{l}978 \\
(\text { sHY: FY 7:10) }\end{array}$ & "Southern barbarians" & 10,ooojin \\
\hline 8. & 983 & Jiaozhi $^{\mathrm{b}}$ & $200 j i n$ \\
\hline
\end{tabular}

(sHY: FY 4: 22)

a Quanzhou is a prefecture-level port city in Fujian, China. It was a capital of Qingyuan that was conquered by the Northern Song dynasty in 978 and later became a center of the Song maritime trade.

b Jiaozhi, located in present-day northern Vietnam.

75 Tong zhi, 76: 875-1.

76 For the history of the frankincense trade, see Nigel Groom, Frankincense and Myrrh: A Study of the Arabian Incense Trade (London-Beirut: Longman and Librairie du Liban, 1981); David Peacock, and David Williams, Food for the Gods: New Light on the Ancient Incense Trade (Oxford: Oxbow Books, 2006). 
TABLE 7 The maritime frankincense trade during the Northern Song (cont.)

\begin{tabular}{|c|c|c|c|}
\hline & Date & Origin & Quantity \\
\hline 9. & $\begin{array}{l}993 \\
(s s \text { 490: 14119) }\end{array}$ & Dashi & 18oojin \\
\hline 10. & $\begin{array}{l}995 \\
(s s \text { 490: 14119) }\end{array}$ & Dashi & unspecified \\
\hline 11. & $\begin{array}{l}1015 \\
(s s \text { 489: 14097) }\end{array}$ & Chola & 6ojin \\
\hline 12. & $\begin{array}{l}1018 \\
(\text { ss 489: 14083 } \\
\text { sHY: FY 4: 69) }\end{array}$ & Champa & 5ojin \\
\hline 13. & $\begin{array}{l}1018 \\
(s H Y: F Y 7: 21)^{\mathrm{c}}\end{array}$ & Srivijaya & 81,68o jin \\
\hline 14. & $\begin{array}{l}1029 \\
(s H Y: F Y 4: 69)\end{array}$ & Champa & 2000 jin \\
\hline 15. & $\begin{array}{l}1030 \\
(s s \text { 489: 1084; } \\
\text { sHY: FY 4: 7O) }\end{array}$ & Champa & $2000 j i n$ \\
\hline 16. & $\begin{array}{l}1068 \\
(s s \text { 489: 14085) }\end{array}$ & Champa & unspecified \\
\hline 17. & $\begin{array}{l}1070 \\
(s H Y: F Y 7: 32)\end{array}$ & Dashi & unspecified \\
\hline 18. & $\begin{array}{l}1072 \\
\left(s H Y: F Y 7: 3^{2}\right)\end{array}$ & Dashi & unspecified \\
\hline 19. & $\begin{array}{l}1072 \\
(\text { sHY: FY 7: 32; 4: 71) }\end{array}$ & Champa & unspecified \\
\hline 20. & $\begin{array}{l}1073 \\
(\text { SHY: FY 4: 92) }\end{array}$ & Dashi & unspecified \\
\hline 21. & $\begin{array}{l}1077 \\
(s s \text { 489: 14099) }\end{array}$ & Chola & unspecified \\
\hline
\end{tabular}

c A note from Shang tang kao suo.

If the Romans caused the rise of frankincense fashion in Europe, then it was definitely during the Song period that the Chinese passion for this incense made it popular in Asia. During the Song period, frankincense was one of the most-traded drugs and aromatics in China and was viewed mainly as a product from the lands of the Dashi and the Qarakhanids (Tables 6 and 7). Arab merchants transported their commodities, including frankincense, to China by sea 
and used Srivijaya on the island of Sumatra as a transshipment point. Zhao Rugua recorded that frankincense came from the three Arab countries known as Mirbat, Shihr and Dhofar, located in present-day Oman and Yemen, and it was first shipped to Srivijaya for barter and after that to China. ${ }^{77}$ Therefore, the official histories of the Song dynasty recorded Srivijaya and other countries in Southeast Asia as places that imported frankincense to China. It should be noted that Southeast Asia served in Song China as the main source of luxury goods supplied by Persian, Arab and Indian traders.

Studies on the ancient Incense Road mainly deal with the transportation of frankincense and myrrh from Arabia to the Mediterranean region. Even when China is noted as one of the centers of the aromatics trade, it is often discussed in the context of the international maritime network. However, frankincense was transported to Song China both by sea and overland. This section of the continental Frankincense Road has rarely attracted scholarly attention.

The main suppliers of this incense to China via overland roads were the Qarakhanids. They brought it in such great quantities that the Chinese recorded it as a product of the Qarakhanid lands. ${ }^{78}$ What was the origin of frankincense brought by the Qarakhanids? They could certainly obtain it from India. Ghaznavid sources recorded frankincense in a list of gifts presented to the Qarakhanids by Sultan. ${ }^{79}$ However, an influx from India probably was not enough to meet the demands of the frankincense trade of the Qarakhanids in the East. In his descriptions of frankincense (kundur and lubān), al-Bīrūnī mainly described the varieties of Arabian origin. He mentioned Indian frankincense saying that it was bitter and green, and was inferior to the Shihr variety. ${ }^{80}$ It means that Indian frankincense was less-prized even in the Ghaznavid realm.

Qarakhanid merchants supplied this gum-resin not only to China in great quantities (up to 100,00o jin), but to other polities located on their road to China. The Guazhou and Shazhou Uyghurs, as well as the Tsongkha kingdom re-gifted frankincense to Song China, as can be seen from the table below. South Arabia and East Africa always remained as main sources from which the pre-modern world obtained its most valued gum-resin. Its quality was most likely different from the Indian type, as it had been transported in large amounts to South Asia since ancient times. Therefore, the gum-resin that the Qarakhanids obtained from the Ghaznavids were probably mostly of South Arabian or East African origin.

77 Zhu fan zhi, trans. Hirth and Rockhill, 195.

78 Song shi, 490: 14108.

79 Kitāb al-Yamin̄i, trans. Reynolds, 316.

8o Kitāb al-șaydana fì al-țībb, ed. and trans. Said, 283, 291, Arabic text 324-325, 329-330. 
Commodities brought by the Qarakhanids to China are often depicted as tributes offered to the emperor. Some items certainly served as diplomatic gifts, but most were transported exclusively for trade. Tributary relations were an official form of trade with Imperial China along the Silk Roads from the very beginning. The Qarakhanids sent envoys to China to conduct trade in the name of contributing to the Song dynasty. Merchants also sometimes acted as envoys. Frankincense was a trade product that brought enormous profit for the Qarakhanids in China. They supplied it not only to the court but also sought to trade in private markets in China. Their activity even caused the expansion of the state's monopoly on frankincense. In 1078 Emperor Shenzong of Song issued an edict prohibiting frankincense import for Qarakhanid merchants:

地產乳香, 來輙羣負, 私與商賈牟利; 不售, 則歸諸外府得善價, 故

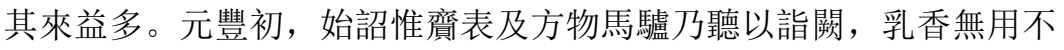
許貢。 81

The land produces frankincense and when they arrived they always carried it in great numbers and privately benefited from it with merchants and businessmen; if it was not sold out, then they returned it to waifu [Outer Treasury] at a good price, therefore, they came more and more. In the beginning of the Yuanfeng era [1078], Imperial Edicts began to be issued that stated to bring only a memorial as well as local products, horses and donkeys to get permission to pay a visit to the court and if frankincense was not required, it was not permitted to be offered.

Two years later after the state embargo on frankincense, a Qarakhanid delegation arrived at the court with 100,000 jin of frankincense that was stopped due to the imperial interdict. ${ }^{82}$ This delegation started their mission before the edict was issued and was not aware of new regulations. It was the last Qarakhanid caravan to carry frankincense, according to the official Chinese sources. Due to this interdict, Qarakhanid merchants suffered great losses. The price of frankincense was around 1.4 guan for each jin. It is clear from the following official report:

于闐國進奉使羅阿廝難撒溫等有乳香三萬一千餘斤, 為錢四萬四千餘 貫，乞減價三千貫賣於官庫。83

81 Song shi, 490: 14108.

82 Xu zizhi tongbian changbian, 309: 7506; Song huiyao jigao, Fanyi 4: 16, 7: 36.

83 Song huiyaojigao, Fanyi 4: 6. 
The envoy of the Yutian [Khotan] state, Luo Asinan Sawen [Boyla Arslan Saghun], and others that came with offerings had more than 31,00o jin of frankincense worth more than 44,0oo guan, they asked to reduce the price by 3,0oo guan and sell it to the official treasury.

During the Song period, 1 guan was equivalent to a string of 1000 wen, the smallest unit of traditional Chinese copper coins. Sometimes 1 guan could contain fewer coins but rated as equivalent to a full string of 1000 coins. For comparison of prices, it is necessary to point out that the daily income of the lower-class people living in the countryside during the Northern Song period was around 100 wen, which was equivalent to the price of 1 dou of rice or 1 jin of beef or fish in some provinces. The average income of people in the cities was 300 wen. The official minimum the cost of living in Kaifeng was 20 wen a day. ${ }^{84}$

It seems that the state tried to control the frankincense trade and prohibited the import via the overland roads, mostly used by Qarakhanid merchants for this purpose. Therefore, the edict on the embargo of frankincense stopped its transportation via the continental roads.

TABLE 8 The continental frankincense trade during the Northern Song

\begin{tabular}{|c|c|c|c|}
\hline & Date & Origin & Weight \\
\hline 1. & $\begin{array}{l}1007 \\
(s H Y: F Y 5: 3)\end{array}$ & Guazhou and Shazhou & unspecified \\
\hline 2. & $\begin{array}{l}1010 \\
(s H Y: F Y 4: 14)\end{array}$ & Kucha & $\begin{array}{l}\text { 249jin, 69jin } \\
76 \text { jin, 39jin }\end{array}$ \\
\hline 3. & $\begin{array}{l}1023 \\
(s S 49 \circ: 14124 \\
\text { SHY: FY 5: } 3)\end{array}$ & Shazhou & unspecified \\
\hline 4. & $\begin{array}{l}1024 \\
(\text { sHY: FY 4:15) }\end{array}$ & Kucha & unspecified \\
\hline 5 . & $\begin{array}{l}1025 \\
(X Z T C \text { 103: 2394; } \\
\text { sS 9: 181, 490: 14108; } \\
\text { SHY: FY 7: 23) }\end{array}$ & Qarakhanids & unspecified \\
\hline 6. & $\begin{array}{l}1025 \\
(\text { SHY: FY 4: 9) }\end{array}$ & Ganzhou & unspecified \\
\hline
\end{tabular}

84 For more details on cost of living and prices, during the Song period in China, see Cheng, "Songren shenghuo shuiping," 100-101. 
TABLE 8 The continental frankincense trade during the Northern Song (cont.)

\begin{tabular}{|c|c|c|c|}
\hline & Date & Origin & Weight \\
\hline 7 . & $\begin{array}{l}1025 \\
(s s \text { 490: 14117) }\end{array}$ & Uyghurs & unspecified \\
\hline 8. & $\begin{array}{l}1027 \\
(s H Y: F Y 7: 23)\end{array}$ & Ganzhou & unspecified \\
\hline 9. & $\begin{array}{l}1028 \\
(s H Y: F Y 7: 23)\end{array}$ & Ganzhou & unspecified \\
\hline 10. & $\begin{array}{l}1031 \\
(s H Y: F Y 7: 24)\end{array}$ & Kucha & unspecified \\
\hline 11. & $\begin{array}{l}1037 \\
(\text { sHY: FY } 7: 25)\end{array}$ & Kucha and Shazhou & unspecified \\
\hline 12. & $\begin{array}{l}1041 \\
(s H Y: F Y 7: 26)\end{array}$ & Uyghurs & unspecified \\
\hline 13. & $\begin{array}{l}1071 \\
(X Z T C \text { 220: 5349; } \\
\text { SS 15: 279, 490: 14108; } \\
\text { SHY: FY 7: 32) }\end{array}$ & Qarakhanids & unspecified \\
\hline 14. & $\begin{array}{l}1072 \\
\left(s H Y: F Y 7: 3^{2}\right)\end{array}$ & Kucha & unspecified \\
\hline & $\begin{array}{l}1073 \\
(s H Y: F Y 7: 33)\end{array}$ & Qarakhanids & unspecified \\
\hline 15 . & $\begin{array}{l}1074 \\
(X Z T C 250: 6 \circ 82 \\
\text { ss 15: } 285 \\
\text { SHY: FY 7: } 33)\end{array}$ & Qarakhanids & unspecified \\
\hline 16. & $\begin{array}{l}1077 \\
(X Z T C 281: 6891 \\
\text { SHY: FY 7:33) }\end{array}$ & Qarakhanids & unspecified \\
\hline 17. & $\begin{array}{l}1077 \\
(\text { XZTC 285: } 6972 \\
\text { SHY: FY 4: 16) }\end{array}$ & Qarakhanids & 31,ooo jin \\
\hline 18. & $\begin{array}{l}1077 \\
(s s \text { 492: 14164) }\end{array}$ & Tsongkha & unspecified \\
\hline 19. & $\begin{array}{l}1080 \\
\text { (XZTC 309: } 75 \circ 6 \\
\text { SHY: FY 4: } 16,7: 36 \text { ) }\end{array}$ & Qarakhanids & 100,ooo jin \\
\hline
\end{tabular}


The table on the continental frankincense trade is only a rough estimate, but it reflects the general situation (Table 7). It demonstrates that the resin began to be transported to China after the conquest of Khotan by the Qarakhanids at the beginning of the eleventh century. The first mission to present frankincense to China arrived from the Guazhou and Shazhou Uyghurs in 1007. It was most likely obtained from the Qarakhanids. Therefore, it can be concluded that the Qarakhanids immediately initiated contact with their eastern neighbors to build a bridge towards China. This plan worked out, and the first mission from the Qarakhanids to the Song court arrived in 10og. The Qarakhanid envoy also pointed out that it was possible due to the peaceful roads between Khotan, Guazhou and Shazhou. ${ }^{85}$

Kucha also sent an envoy to present frankincense to the Song court in 1010. It is not clear when the Qarakhanids conquered the Kucha kingdom. But in 1010 it was most likely not yet under Qarakhanid control. If Kucha had access to frankincense at that time, it means that the Qarakhanids sought to establish diplomatic and trade relations with the kingdom in the very beginning. Later the Qarakhanids became almost the only supplier of frankincense along the overland roads. Due to the Tangut conquest of most of the Uyghur polities located in the Hexi Corridor, Qarakhanid trade along these territories was probably limited. The Qarakhanids arrived in China mainly via the Tibetan Tsongkha kingdom during this time and also likely supplied frankincense to the Tsongkha market, as can be assumed based on the list of gifts presented to the Song emperor by the Tsongkha ruler. Frankincense was recorded in this list. ${ }^{86}$ The Qarakhanids periodically tried to regain access to the territories occupied by the Tanguts and even dispatched an army against them. ${ }^{87}$ It was not the only attempt to return control over the main roads to China. These roads were the sources of wealth and power.

Frankincense was not the only highly valued commodity traded in China by Qarakhanid merchants. According to the edict on frankincense, the emperor ordered the caravans to bring horses and donkeys instead of frankincense. The price of a non-military horse in Kaifeng was around 10 guan in 1072 and the price of non-Chinese horses from the southwestern regions that were used mainly for military purposes was around 100 guan during the Southern Song period. ${ }^{88}$ The Qarakhanid delegation received 1,200,00o guan for horses from

85 Song shi, 490: 14107 .

86 Ibid, 492: 14164 .

87 Ibid, 49o: 14109 .

88 Cheng, "Songren shenghuo shuiping," 109-110. 
the emperor in $1085 .{ }^{89}$ If the cost of one horse was equivalent to 100 guan, then it means that the Qarakhanids offered 12,00o horses. Qarakhanid merchants could also receive more rewards than the profits from their commodities. It is obvious that frankincense was much easier to transport and could bring almost the same profit in the Chinese market as horses. It seems that Qarakhanid merchants preferred to export frankincense rather than horses, and the emperor decided to change the situation and encourage Qarakhanid merchants to bring more horses by prohibiting the frankincense trade.

The Song Tea and Horse Agency was created in 1074 to monopolize a tax-free industry of Sichuanese tea to finance war horses, which were a crucial component of defense. It was the first time that the tea industry was subjected to centralized control and it served for the state involvement in the entire regional economy. The state-run tea and horse trade was established as a result of Song economic activism in the geopolitical context. Song policymakers were aware of their military weakness compared to the neighboring nomadic empires due to the limited access to the most productive pastoral lands of Asia and foreign horse suppliers. Therefore, the Song tea market was created to buy Sichuanese tea and trade it for cavalry horses. ${ }^{90}$

The main horse supplier of Song China was Tibet. For this reason, the commercial network of trade routes that ran between Song China and Tibet is known among historians as "the Tea and Horse Road." The Tibetans used the Qinghai Road that also linked Central Asia and China. They did not depend on the Hexi Corridor, which was controlled by the Tanguts during this time. Chinese history and art sources also describe the activity of Qarakhanid merchants along this road. This means that Qarakhanid merchants had an alternative route into China when it was not possible to negotiate with the Tanguts. This chapter deals with the role of the Qarakhanids in the Song tea and horse trade.

\subsection{The Tibetan Passage}

The Silk Roads that connected China with Central Asia is known as the Hexi Corridor Road, which was divided into two directions in Dunhuang to the

$89 \quad$ Xu zizhi tongjian changbian, 361: 8638; Song huiyao jigao, Fanyi 4: 17; 7: 38.

9o For the study on the tea industry during the Song period and the tea and horse trade, see Smith, Taxing Heaven's Storehouse, 1991. 
Northern and Southern Roads. There was also a lesser-known passageway located on the Tibetan Plateau that began after the Qarakhanid city Cherchen probably in the ancient city known in today as Miran. Here the Southern Silk Road was divided into two parts: the first part continued to the east and the second part to the southeast through the Qinghai region (See Map 2). Travelers had to cross the Altun Mountains and the Qaidam Basin, passing the Qinghai Lake and present-day Xining, which was known as Qingtang during the Song period and controlled by the Tsongkha kingdom. From Qingtang the road led further to the east to the Song Xihe Circuit, to Kaifeng and to the Sichuan, the center of the tea markets. The Qinghai Road was not an invention of this time. It functioned between China and Tibet during the rule of Tuyuhan and Tubo peoples in the Qinghai region as confirmed by Chinese records and archaeological data. ${ }^{91}$ According to Makiko and Asanobu, the Qinghai Road has been completely neglected in the research until recently. However, archaeological discoveries in Miran and the Qinghai region, particularly in present-day Dulan, confirm the active usage of the road, especially during the Tibetan Empire. ${ }^{92}$ Almost nothing is known about this road after the Tang period. The eleventhcentury Song map Huayi tu that has been discussed above depicted the Qinghai region. I believe that archaeological excavations can provide more data about its role during the Tsongkha period and probably unveil some aspects of the Qarakhanid trade in Tibet and China. Indeed, the Qarakhanids used the Hexi Corridor but also passed through the Qinghai Road. The Tibetan passage was used as an alternative road to reach the Song capital and as the main link to the Tea and Horse trade in China.

\subsection{Qarakhanid Tea and Horse Trade}

Emperor Shenzong of Song issued an edict in 1078 that allowed Qarakhanid merchants to purchase tea without tax:

元豐元年六月九日, 詔提舉茶場司: 于闐進奉使人買茶與免稅, 於歲 額錢內除之。93

On the ninth day of the sixth month of the initial year of the Yuanfeng era [July 20, 1078], Imperial Edict to tiju [Intendant] of the chachang si [Tea Market Agency]: "Envoys who came with offerings from Yutian [Khotan]

$91 \quad$ Makiko Onishi and Asanobu Kitamoto, "A Lesser Known Route."

92 Ibid.

93 Song huiyao jigao, Fanyi 4: 16. 
are allowed to buy tea with tax exemption, and it is granted within the annual fixed amount of money."

This edict made the Qarakhanids active in the tea and horse trade. They were capable of supplying a good amount of cavalry horses. As will be remembered from the previous chapter, the Qarakhanid delegation brought 1,200,000 guan worth of horses in $1085 .{ }^{94}$ When the tea and horse trade was integrated into a single state operation in 1074, it made horse procurement a decentralized and regionally-based process. This means that horse suppliers were allowed to come directly to the tea markets in the regions. Previously, they were required to assemble their herds in frontier markets and then lead them to Kaifeng. This change made the whole operation less expensive and relieved the central government to manage and subsidize the purchase of horses. ${ }^{95}$

The Qarakhanid image as horse suppliers was depicted by the Northern Song painter and statesman Li Gonglin in his Wuma tu (Portrait of Five Horses) created in 109o. Li Gonglin was proficient in painting figures, flowers, birds, and landscapes, and was especially good at horse painting. His Portrait of Five Horses is divided into five sections. Each section depicts a tributary horse from the Western Regions led by a horseman and contains inscriptions recording detailed information about horses that was written by the Northern Song poet and calligrapher Huang Tingjian (1045-1105) ${ }^{96}$ Based on their physical features and clothing, the first three horsemen are most likely foreigners from the Western Regions, and the last two men can be identified as Han Chinese. ${ }^{97}$ One of the foreign horsemen who lead the Khotan horse is indeed from the Qarakhanid realm. He wears a robe and a hat that resemble traditional Central Asian chapan and qalpaq (Figure 9). The image contains an inscription, which reads:

右一匹元祐元年十二月十六日左麒麟院收于阗国进到风头骢八岁五尺 四寸98

The horse on the right: On the sixteenth day of the twelfth month of the initial year of the Yuanyou era [January 22, 1087], the Left Qilin Yuan ${ }^{99}$

94 Xu Zizhi tongjian changbian, 361: 8638; Song huiyao jigao, Fanyi 4: 17; 7: 38.

95 Smith, Taxing Heaven's Storehouse, 249-251.

96 Zhang, Li Gonglin, 7-12. For the recent full-scale reproduction also, see Itakura, 2019.

97 Zhang, Li Gonglin, 49.

98 Ibid, 7 .

99 The Left Qilin Yuan was one of the imperial stables of the Northern Song. 
received a piebald named "Phoenix-Head" presented by Yutian [Khotan]. It is eight years old and its height is 5 chi and 4 cun.

Why did the Qarakhanids seek access to the tea trade with Song China? One possible reason for that could be that Chinese tea began to be valuable in Central Asia. Records on Chinese tea in Central Asia from that period described its health benefits. The most detailed description was provided by al-Bīrūnī in his Book on Pharmacy and Materia Medica:

Tea [chä $i]$ - It is said that $\operatorname{ch} \bar{a} h$ is a Chinese [Șin̄i $]$ word and is meant for a herb which grows at high altitudes there. It also grows in Khitay [Khațā] and Nepal. Several varieties of it are distinguished on the basis of its color: some are white, while the others are green, violet, grey, and black.

White tea is the most excellent variety of the herb; its leaf is slender and fragrant, and exerts its effect on the body comparatively more swiftly than all the other varieties. It is rare and difficultly available, followed with regard to availability by the green, violet, grey, and black varieties.

The people cook it, and preserve it in a cube-shaped vessel after desiccating it. It has the characteristics of water but is especially beneficial in overcoming the influence of bibulation. For this reason, it is taken to Tibet where people are habituated to quaffing considerable quantities of wine there is no better medicine for negating the effect of liquor than this herb. Those who transport it to Tibet accept nothing in barter but musk.

In the book, Akhbār al-Şin it has been stated that thirty bags of tea cost a dirham, and its taste is sweet coupled with sourness. On boiling, however, the sourness disappears.

The people drink it. It is said that they drink it with hot water and believe it to be a cholagogue and blood purifier.

A person who traveled to the place of its occurrence in al-Ṣin [Song China] has stated that the king of that country resides in the city of Yanjū [this can be also read as Banjū]. A big river like the Tigris traverses through this city. Both sides of the river are studded with wine sellers' tenements, kilns and shops. ${ }^{100}$ People flock there to drink tea, and do not take Indian cannabis clandestinely. The king of the place receives the capitation tax, and the public cannot transact the sale of tea, since both tea and wine are in the possession of the king. He who transacts business in salt and

100 This description refers to Bianjing, the capital of Song China, which located along the Yellow River's southern bank. 
tea without the king being aware of it is awarded the punishment due to a thief. And the people there slay the thief and eat his flesh.

Profit from such places goes to the coffers of the king and such profits equal those accruing from gold and silver mines. Some physicians have mentioned in their pharmacopoeia that tea is the plant produced in al-Ṣin. The people of that country make tablets from it and take them to foreign lands. ${ }^{101}$

The author clearly stated that he collected this information from a person who traveled to China as well as from other scholarly books that existed during his time. It seems that tea began to be transported to Central Asia before the Qarakhanids received direct access to the tea trade in Song China followed by the imperial edict in 1078. The Qarakhanids could obtain tea from the Khitans, the Tanguts, and the Tibetans, who did not produce tea but received it from trade and gifts with the Song dynasty. The al-Bīrūnì's note demonstrates that tea was imported from the Khitan realm to Central Asia. The same likely applied to Nepal. The tea plant (Camellia sinensis) is native to East Asia and the Indian subcontinent. But there is no historical documentation of tea production in Nepal during this period. It seems that Nepal obtained tea from Tibet via the Tea and Horse Road and transported it to Central Asia.

At the same time al-Bīrūnī also clearly described the tea monopoly in China. As tea consumption and the tea trade assumed visibility in the economy of the empire, the government sought to tax it. The taxation of tea in China began during the Tang and developed into a state monopoly over all the tea produced in the empire. Allowing Qarakhanid merchants to buy tax-free tea from the Tea Market Agency demonstrates the imperial interests in the Qarakhanids as a horse supplier.

When Chinese tea began to be introduced to Central Asia it was known by different terms. This explains why tea did not appear in the Qarakhanid sources. For instance, in the list of gifts presented by Yusuf Qadir Khan to Sultan Mahmud of Ghazna, Gardizì mentioned a Chinese commodity called dārkhäshāk Chīni. ${ }^{102}$ Barthold, the first scholar who published a part of Gardizīs history found this word indecipherable. ${ }^{103}$ Habībì suggested that it can be connected with the term khār Chìnī / khär Șin̄in, which means a hard substance used to make things like bells, cooking vessels, etc. ${ }^{104}$ I argue that it

\footnotetext{
101 Kitāb al-șaydana fì al-țībb, ed. and trans. Said, 105, for the Arabic text, see 128.

102 Zayn al-akhbār, ed. Ḥabībī, 189; Zayn al-akhbār, trans. Bosworth, 95, 142, see n. 69 .

103 Bartold, Turkestan, 346, n. 2.

104 Zayn al-akhbār, ed. Habībī, 189, n. 5; Zayn al-akhbār, trans. Bosworth, 142, n. 69.
} 
can be a combination of the words dāru (medicine, drug) and khāshāk (leaves, sprigs), meaning Chinese tea, which was one of the important commodities transported by the Qarakhanids from China along with silk and silver.

Furthermore al-Bīrūnī mentioned other scholarly works on the pharmacy that described Chinese tea. These works have not survived. However, he provided a legend on the origin of the Chinese tea that he obtained from one of these works:

These pharmacopoeias also describe the origin of tea. A Chinese king became displeased with one of his courtiers whom he exiled from the city in the direction of the mountains. The courtier was seized by a fever, and one day he trudged, in a desperate state, towards the mountain valleys. He was being gnawed by hunger and he only saw tea plants, whose leaves he ate. After a few days, his fever began to abate. He continued eating tea leaves till he recovered from the fever completely. Another courtier happened to pass this way. He saw the courtier who had staged this remarkable recovery and informed the king about it. The king was surprised at this and he called the exiled courtier to his court. He was rather pleased to see that the courtier had become healthy as he was before the exile and enquired from him the reason for his recovery. The courtier thereat narrated the remarkable medicinal properties of tea. The king thereupon ordered that tea should be tested, and his physicians enumerated its advantages to him. They also began to incorporate tea in medicines. ${ }^{105}$

It is plausible that the legend was introduced by merchants who traveled to China and heard these stories there.

According to the description of al-Bīrūnī, Chinese tea was highly valued for its medicinal purposes and cost a dirham for thirty bags. Cheng Minsheng, in his research on living standards and monetary values of the Song dynasty, also provided tea prices. Thus, the price of a cup of tea in Hangzhou at goulan, a traditional Chinese theater performing singing and dancing, was 1 wen in 1072. The price of 1 jin of inferior tea was 100 wen in the Jingmen area at the end of the Shaoxin era (1131-1162). ${ }^{106}$ The Song government, especially during the twelfth century, issued tea licenses in different types for merchants. Thus, there were "long licenses" (changyin) costing up to 5 o guan for 1500 jin of tea, and "short licenses" (duanyin) starting from 10 guan for $300 \mathrm{jin} .107$

105 Kitāb al-șaydana fí al-țībb, ed. and trans. Said, $105^{-106}$, for the Arabic text, see 128-129.

106 Cheng, "Songren shenghuo shuiping," 107-108.

107 Smith, Taxing Heaven's Storehouse, 69-70. 
The main horse suppliers of Song China were unequivocally the Tibetans, who exchanged their horses for tea. At the same time, the Qarakhanids managed to obtain a tea tax exemption as a reward for their commodities. They were able to supply horses for exchange as well as utilize cash obtained from the emperor. The main idea of the Tea and Horse Agency was to strengthen the defenses of the state and stabilize the frontier through a regular supply of horses. Therefore, the Qarakhanids obtained access to this network mainly due to their horses. The Qarakhanids' interest in the tea trade was directed by the rise of demand for tea in the Qarakhanid realm and beyond.

\section{Conclusion}

The so-called Silk Road symbols as huren images disappeared after the Tang period. Despite the existence of some rare figurines of foreign merchants and artists unearthed from Liao and Song tombs, and paintings of foreign envoys created by the Song artists, it can be concluded that the representation of foreigners in the Song arts was not common. This applies not only to caravan travelers but also to maritime traders, who widely traded and settled in Song China. However, the examined Chinese texts confirm the large-scale Qarakhanid trade in China. Qarakhanid trade caravans were capable of transporting up to 100,000 jin of frankincense, which was equivalent to 64,000 kilograms during the Song period. The camel was the most efficient type of pack animal for longdistance caravans. Actual carrying capacity varied with the breed of camel, the temperature, and the road conditions, but they could typically carry between ${ }^{11} 5^{-295} \mathrm{~kg}$ and cover thirty-two to forty kilometers per day. ${ }^{108}$ On longer trips camels usually carried substantially less than the average. This means that Qarakhanid caravans employed about 5 oo camels just for the transportation of frankincense. Besides the Qarakhanids offered horses equivalent to 1,200,000 guan that roughly corresponds to 12,00o heads. Moreover, the Qarakhanid amber trade in China depicted in the Song dynasty texts is also confirmed by a large number of amber items of Baltic origin found in Liao tombs. It should be noted that amber appeared in the list of gifts to the Song emperors presented by the Khotan kingdom as well as the Uyghur polities in Gansu and the Tarim Basin long before the Qarakhanid conquest of Khotan. This commodity from the west could arrive exclusively via the Qarakhanids. Therefore, the Qarakhanid commercial presence in the East can be confirmed starting from

108 John B. Friedman et al., eds., Trade, Travel and Exploration in the Middle Ages: An Encyclopedia (London: Routledge, 2017), 95. 
the 960 os at the latest. It explains the existence of the rich findings of Islamic glass vessels and Baltic amber items in the early eleventh-century Liao tombs.

During the Qarakhanid era, the Amber Road from the Baltic region and the Incense Road from Arabia did not stop in the Mediterranean region but continued to Central Asia and further on to East Asia. The Tea Road was not only used by Tibetans to transport Chinese tea to India; Qarakhanid merchants also used it in the direction of Central Asia and introduced new culture to the region. The long-distance trade of commodities played a significant role in forming political structures and transferring socio-cultural practices among the centers of ancient civilization in the pre-modern world. Highly prized plant components that moved along ancient routes such as amber, frankincense, and tea not only transformed aesthetics and cuisines, but they also often, and sometimes even more importantly, played significant roles in economic, cultural, and ritual contexts. The Qarakhanids sought to gain access to and control over these trade goods that served as the source of great wealth and political power, which lead them to mount major trade expeditions, new trade routes, and even war. 